\title{
The Tax Cut and Jobs Act (2017) as a Driver of Pension Derisking: A Comprehensive Examination
}

\author{
Divya Anantharaman \\ Rutgers Business School \\ Saipriya Kamath \\ London School of Economics \\ Shengnan Li \\ Rutgers Business School
}

\begin{abstract}
:
Corporate defined-benefit (DB) pension sponsors in the US are increasingly on a path of "derisking" - by moving pension assets away from equities and towards fixed-income securities that better match the obligations, or by transferring obligations off their balance sheets entirely, via settlements with insurance companies or lump-sum payouts to beneficiaries. In this study, we examine whether the Tax Cut and Jobs Act of 2017 ("TCJA") served as a driver of pension derisking. Examining behavior in the window between the TCJA's announcement and its lower tax rate going into effect, we document that sponsors with stronger incentives to derisk their pensions tend to contribute more into their plans in that window, while deductions can still be taken at the higher tax rate - specifically, sponsors expecting large and uncertain contribution requirements for pensions in the future, facing high regulatory costs to maintaining plans, and with competing demands on cash flows. Examining behavior after the TCJA goes into effect, we document that the firms with the largest TCJA-triggered contributions also engage in more derisking subsequently, both by shifting asset allocations and by transferring obligations to other parties. In sum, our findings point to the TCJA having acted as a trigger for what could be a fundamental reorganization of the DB pension landscape in the US.
\end{abstract}

Keywords: TCJA; defined-benefit plans; voluntary contributions; derisking; pension asset allocation; pension settlements or buyouts

JEL Classification: J32, K34, H32, H26, G23 


\section{INTRODUCTION}

Defined Benefit (DB) pensions are an economically significant source of retirement income in the United States (US). About 37 million private sector workers rely on one of the 25,000 DB plans sponsored by the Pension Benefit Guaranty Corporation (PBGC) for retirement income. $^{1}$

A key feature of DB plans, which differentiates them from defined contribution (DC) plans, is that the responsibility for funding future benefits falls primarily on the company sponsoring the plan ("sponsor"). As benefits are often due far into the future and subject to myriad uncertainties ${ }^{2}$, a DB plan sponsor is exposed to a range of risks. Underfunded plans can generate large cash contribution requirements arising from federal pension funding regulation in the US. Plans are often heavily invested in equity markets; market movements make required contributions volatile and unpredictable. Macroeconomic and demographic trends add further uncertainty to contributions - falling interest rates and rising longevity expectations increase estimates of pension obligations, requiring greater contributions to maintain minimum funding levels. Large and unpredictable contribution requirements, in turn, act as a constraint on sponsors' investment activities (Campbell, Dhaliwal, and Schwartz, 2012; Cooper and Ross, 2001; Rauh, 2006).

Unsurprisingly, a conversation on "derisking" can increasingly be heard in the corporate DB pension arena around the world. ${ }^{3}$ Sponsors are employing a range of strategies to reduce or remove the many risks associated with DB plans (e.g., interest rate risk, longevity risk, market

\footnotetext{
${ }^{1}$ PBGC Annual Report 2018, available at: https://www.pbgc.gov/sites/default/files/pbgc-annual-report-2018.pdf. In 2017, US Compustat firms sponsoring DB plans represented 55\% of the aggregate market capitalization of all US public firms and reported $\$ 2.7$ trillion ( $\$ 2.3$ trillion) in DB pension obligations (assets).

${ }^{2}$ E.g., on when employees will retire, what their final salary will be at retirement, what form of benefit they will elect, and how long they will live post-retirement - to name a few.

${ }^{3}$ For example, see https://www.cfo.com/retirement-plans/2019/12/for-many-cfos-pension-plans-are-millstonesaround-the-neck/; https://www.cfo.com/retirement-plans/2014/10/voluntary-benefits-a-benefits-balancing-act/; https://buck.com/losing-sleep-over-pension-financials-not-these-cfos-heres-why/.
} 
risks). Some sponsors are shifting pension asset portfolios away from equity and toward fixedincome investments, to better match pension assets with bond-like pension liabilities (an approach varyingly described as asset-liability matching - "ALM", or as "liability-driven investing" "LDI"). Other sponsors are resorting to selling their DB obligations to insurance companies in "pension risk transfer" (“PRT") transactions, of which a record number occurred in $2019 .{ }^{4}$

Discussions in the media and by pensions commentators point to certain regulatory triggers for increased derisking activity. One regulatory force often described as a "tailwind" for pension derisking is the Tax Cuts and Jobs Act of 2017 (the "TCJA"), one of the most dramatic changes to the US tax landscape in decades. ${ }^{5}$ A survey of US CFOs indicated an increased "appetite for pension derisking" (CFO Research 2018); a substantial majority of CFO respondents were mulling pension risk transfers under the new tax regime. The goal of our study more broadly is to understand the impact of the TCJA on pension risk, and more specifically, to examine whether the TCJA served as a driver of pension derisking.

Tax incentives are known to be an important driver of DB pension policy, as contributions to DB plans can be deducted from the sponsor's taxable income within certain limits, and all earnings within the pension fund are tax-exempt. The TCJA decreased the tax burden on US corporations by eliminating the four-step graduated tax rate structure (with a highest rate of 35\%), replacing it

\footnotetext{
${ }^{4} \mathrm{GM}$ and Verizon were early movers in a recent wave of pension risk transfers. The common approach to risk transfer in the US has been through a "settlement" or "buyout", where an insurance company assumes the pension liability in exchange for transfer of a mutually agreed-upon sum of pension assets. The sponsor is left with no further risks or rewards from either pension liability or assets. GM's and Verizon's settlements were the largest and second-largest settlements in US history, transferring \$25bn and \$7.5bn respectively in pension liabilities. Many large sponsors have since followed suit. E.g., see Kozlowski 2018 (Available at: https://www.pionline.com/article/20180412/ONLINE/180419943/aon-u-s-corporate-pension-plan-buyout-volumeto-hold-steady-at-about-25-billion-in-2018), Kharif and Buhayar 2012 (Available at: https://www.bloomberg.com/news/articles/2012-10-17/verizon-to-move-7-5-bln-pension-obligation-to-prudential); and Kozlowski 2020 (Available at: https://www.pionline.com/pension-risk-transfer/corporate-pension-plan-buyoutstop-11-billion-q4-limra)

${ }^{5}$ For example, see CFO.com, June 25, 2018. "Tax law drives pension derisking opportunity", available at: https://www.cfo.com/retirement-plans/2018/06/tax-law-drives-pension-de-risking/
} 
with a flat rate of $21 \%$; this reduction incentivizes firms to accelerate any tax deductions so as to maximize deductions obtained at the higher ("old") rate. One such deduction is the cash contribution towards DB plans. Consistently, starting from late 2017, the news media was replete with reports of large US sponsors making sizeable discretionary contributions to their DB plans, with many specifically citing the tax law changes as motivation. ${ }^{6}$ Gaertner, Lynch, and Vernon (2020, hereafter "GLV") document DB contributions in response to the TCJA to the tune of \$6.3$\$ 7.9$ billion using early data, noting that the full response could be much larger.

A surge in contributions, holding all else constant, improves pension funding - with attendant consequences for pension derisking. One crucial requirement for any derisking strategy, be it a shift in asset allocation to better match pension assets with liabilities, or a removal of the pension obligation from the balance sheet altogether, is to have a well-funded plan. It is believed that many sponsors remain invested in equity securities (despite the advantages of asset-liability matching) because they are reliant on the higher expected returns from equities to "earn their way" out of underfunding. Therefore, asset-liability matching is a feasible solution only for well- or fully-funded plans - industry experts suggest that sponsors have the flexibility to move towards such an investment strategy only when funded status reaches at least $80 \%{ }^{7}$ Similarly, settling pension obligations with an insurer also requires transferring assets at least equal to (or typically

\footnotetext{
${ }^{6}$ Some prominent examples: General Electric announced a discretionary contribution of $\$ 4.5$ billion to its US plans in its 2017 annual report; Lockheed Martin announced that it was contributing \$5 billion to its US plans, adding that it did not expect to make further contributions until 2026 (https://www.pionline.com/article/20180130/ONLINE/180139975/lockheed-martin-to-contribute-5-billion-topension-funds-in-2018); FedEx borrowed $\$ 1.5$ billion for pension contributions in 2018 (https://www.bloomberg.com/news/articles/2018-01-29/fedex-to-sell-bonds-for-pension-contribution-after-taxoverhaul). Also see Goldman Sachs (2018):

https://www.gsam.com/content/dam/gsam/pdfs/institutions/en/articles/pensionsolutions/2018/pension_domino_effect.pdf?sa $=n \& r d=n$

${ }^{7}$ For example, see MassMutual Post-Conference Brief (November 2019). "Pathways to LDI: Ways to reach the right funded status for more flexibility to engage in pension risk control strategies". Available at: https://crainplatform-cpi-prod.s3.amazonaws.com/2019-11/MassMutual_PostConference\%20Brief_11.11.pdf
} 
greater than) the obligation transferred, requiring near-full funding almost as a precondition. ${ }^{8}$ To the extent to which the TCJA spurred a surge in contributions, the resulting improvement in funding status could have catalyzed derisking activities.

To our goal of understanding whether the TCJA drove pension derisking, we examine sponsors' anticipatory behavior before the TCJA goes into effect, as well as actual derisking strategies employed after. In our first set of tests, we examine contributions to DB plans during the "window of opportunity" between the TCJA's announcement and its onset, during which deductions can still be taken at the old tax rate. After estimating TCJA-triggered pension contributions, we examine whether the firms most motivated to derisk their pensions tend to contribute more during this window of opportunity. That is, to the extent to which there is a funding surge in the window, we examine whether derisking concerns drive that surge. In our second set of tests, we examine whether the funding surge triggered subsequent derisking activity. We examine two derisking strategies: first, reducing pension risk while retaining the obligations, by shifting asset allocation away from equities and towards fixed-income investments; and second, engaging in risk transfer transactions that remove pension obligations - with all related risks and responsibilities—off the corporate balance sheet altogether. ${ }^{9}$

\footnotetext{
${ }^{8}$ Prudential White Paper (2019). "Preparing for Pension Risk Transfer". Available at: http://pensionrisk.prudential.com/insights/prt-prep1-preparing-for-prt.php

${ }^{9}$ We find many instances of sponsors citing the TCJA as a trigger for pension derisking. A prominent example is Lockheed Martin, which completed two major risk transfer transactions in 2019 for almost $\$ 2.5$ billion in pension obligations. Kozlowski (2019) reports in an interview with John Mollard (VP and Treasurer, Lockheed) that "the process began with the company's $\$ 5$ billion contribution to its pension plan in 2018...Motivated by the passage of the TCJA,...the company decided to accelerate its contributions to take advantage of the higher tax deduction that was set to expire on Sept 15, 2018...The discretionary contribution allowed the company to have enough assets available compared to its $\$ 43$ billion US DB plan liabilities to make the cost of the transactions palatable." Mollard is further quoted: "Now we can make transactions without having any sort of impact on our income or operating cash flows...If we're ever going to start putting our toe in the water and start going out on the pension risk transfer market, now would be a good time to start." Other sponsors disclose a shift in asset allocation strategies around the events we study, e.g, Weyerhaeuser, which made a voluntary contribution of $\$ 300$ million to US pension plans in 2018, details on its 2018 10-K: "At the end of 2018, we began implementing a change in our asset strategy to an allocation that will more closely match the plan's liability profile going forward, resulting in a larger allocation of
} 
For our first set of tests exploring whether derisking concerns drive contributions in the pre-TCJA window of opportunity, we focus on voluntary contributions - those in excess of contributions mandated by federal pension regulation, and made at the sponsor's discretion. We obtain this information from Form 5500 datasets, which compile plan-level filings made jointly to the Department of Labor (DOL), PBGC and Internal Revenue Service (IRS). ${ }^{10}$ We manually match Form 5500 data (plan-level) to Compustat (firm-level) to obtain sponsoring firm fundamentals, yielding a sample of 3,885 US firm-year observations from 2013-2018. To estimate the increase in contributions triggered by the TCJA, we formally define the window of opportunity as the period after passage of the TCJA (the day it was signed into law) but before its onset (effective date). To be included in this window, therefore, firm-years must meet two criteria: first, there must be sufficient time (at least a day) after the TCJA's passage for the sponsor to make voluntary contributions in response; and second, we must not include any contributions that will only be deducted at the lower ("new") rate. Applying these criteria, as explained in Figure 1, yields a window of fiscal years ending March 31 2017 to November $30^{\text {th }}$, 2018, which we denote the "TCJA period".

We begin by comparing voluntary contributions in the TCJA period with those made in an approximately four-year period prior. We first reaffirm GLV's findings of a significant increase in contributions in the TCJA period for federal-taxpaying firms. We then refine these inferences in two ways: first, the increase occurs only in voluntary (and not for mandatory) contributions, highlighting the importance of focusing on voluntary contributions. Second, the contribution surge

our assets into fixed income securities". Shumsky (2018) in the Wall Street Journal provides more anecdotes: https://www.wsj.com/articles/companies-with-newly-flush-pensions-see-chance-to-unload-the-risk- 1539595800 ${ }^{10}$ The Employee Retirement Income Security Act (ERISA, 1974) first created a framework of funding regulations for DB plans, to ensure benefit security for participants. Amongst other things, ERISA mandated minimum funding levels that plans had to maintain, with resulting mandatory contributions for sponsors whose plans fell short. These requirements are updated periodically through federal legislation, e.g., the Pension Protection Act (2006). 
is much larger than that documented by GLV. For the subset (about $48 \%$ of our sample) that approximates GLV's selection criteria, we estimate that TCJA triggered contributions of \$13.3 $\$ 15.2$ billion, compared to $\$ 6.3-\$ 7.9$ billion per GLV. For our whole sample, a model comparable to GLV's estimates TCJA-triggered contributions at $\$ 37.9$ billion; adding year fixed-effects brings it down to a potentially cleaner but more conservative estimate of $\$ 13.7$ billion. ${ }^{11}$

In our first set of tests examining whether derisking concerns drive the contribution response, we expect the contribution response to be higher from sponsors with relatively poorlyfunded plans, and uncertain benefit payouts in the future. These sponsors can reap the most benefits from achieving (near-) full-funding and proceeding to derisk their obligations now. We find evidence consistent with both predictions, suggesting that the desire to reduce long-term funding risk is a key force shaping the TCJA response. Furthermore, sponsors facing higher PBGC premium costs (which can be eliminated via PRTs) also contribute more. Moving from plan-level to sponsor-level characteristics, we expect that sponsors with higher investment opportunities are more likely to take advantage of the window of opportunity before it closes; DB plans with their unpredictable cash requirements could pose a greater burden for these firms. Despite highinvestment opportunity firms having more competing demands on their resources, we find that they increase voluntary contributions significantly more than firms with lower investment opportunities. We interpret this as high-investment opportunity sponsors attempting to immunize/remove pension risks, so that they can proceed with their investment agenda unhampered by pension funding requirements. We find similarly for dividend-paying firms.

\footnotetext{
${ }^{11}$ Full details of these comparisons are in Tables OA1-OA2 of the Online Appendix. Table OA1 estimates a model similar to GLV's, while table OA2 provides details of calculations used to estimate TCJA-triggered contributions for our approximation of GLV's sample. The calculations for our full sample are in footnote 29.
} 
In our second set of tests, we investigate whether the TCJA drove subsequent pension derisking, through the improved funding that it facilitated. Identifying the sponsors whose pension funding has improved more post-TCJA, we find that these firms also tend to shift their pension asset portfolios away from equity and towards fixed-income securities. We also confirm that shifts in asset allocation occur sharply around the events we study, as opposed to incrementally over time, suggesting that the TCJA acted as an inflexion point for pension asset risk decisions. While this indicates attempts at risk management, we further explore whether the TCJA spurred pension risk transfer ("PRT") transactions, which represent even more drastic attempts to remove pension liabilities (with corresponding assets) off the corporate balance sheet altogether - a recent trend that is as yet not well understood. In exploratory univariate analysis, we find that the more TCJAresponsive sponsors also complete more and larger PRT transactions, through settlements with insurance companies (transferring risks to the insurer), or lump-sum payouts to plan beneficiaries (transferring risks to beneficiaries).

Our study contributes to a deeper understanding of what drives DB policy choices in the realm of funding, asset allocation, and risk management. The twin strategies of shifts away from equity investments and risk transfer transactions have the combined potential to transform the DB landscape in the US, with consequences for the sizeable population dependent on these plans for retirement income. Our evidence is consistent with the TCJA acting as one driver of these trends: ex ante, derisking concerns appear to have driven the rush to accelerate contributions before the new, lower tax rate becomes applicable; and the funding improvement that resulted ex post appears to have spurred increased derisking activity.

At a conceptual level, our findings of improved funding leading to lower risk in pension portfolios represent a marked departure from our prior understanding of this relation: for a 
comprehensive sample of US plans, Rauh (2009) documents that as funding improves, plans tend to invest more in riskier asset classes. Our finding essentially the opposite relation, concentrated around the TCJA's onset, suggests the possibility that in this particular context, firms went down the path of making contributions specifically in order to achieve their derisking goals. This path is made especially attractive by the TCJA's twin effects of accelerating funding and reducing the long-term attractiveness of maintaining a DB plan (by lowering the value of the tax shield it provides), and hinted at empirically by our findings on PRT transactions. As lower-risk, bettermatched pension portfolios are often seen as an important intermediate step towards PRT transactions, we speculate that these twin effects of the TCJA could have delivered the equivalent of a "one-two punch" toward removing DB pension obligations from corporate balance sheets.

We also contribute to the rapidly emerging literature on the consequences of the TCJA (e.g., Amberger and Robinson 2020; Bennett, Thakor, and Wang 2019; De Simone, McClure, and Stomberg 2020; Edwards and Hutchens 2020; Frank, Hoopes, and Lester 2020; Hanlon, Hoopes, and Slemrod 2019). As expected with a regulation as transformative as the TCJA, much work and discussion is needed to draw the big picture of its consequences, and to identify "winners" and "losers". Some robust findings so far include substantial increases in stock buybacks, but no seeming increase in firms' employee counts and wages (Bennett et al. 2019; Cohen and Viswanathan 2019). Alongside GLV, we document consequences - presumably unintended - for the retirement benefits arena. We build on GLV's findings of a funding surge to provide a broader picture of the TCJA's impact on DB pension risk.

As a tertiary contribution, we refine GLV's estimates of the magnitude of pension contributions triggered by the TCJA. While GLV employ an innovative research design that allows a timely identification of the "initial corporate response" to TCJA, that timeliness comes with some 
inherent limitations, which they carefully acknowledge. By examining the complete window of opportunity in which firms can respond and considering a larger sample of firms, we obtain estimates of TCJA-triggered contributions that are about two to five times GLV's estimate (Appendix A provides details, as well as anecdotes of prominent sponsors whose large contributions are captured only with the design we employ).

\section{BACKGROUND AND HYPOTHESES}

\section{Institutional Background}

The US has had one of the highest corporate tax rates for decades, according to the Organization for Economic Co-operation and Development (hereafter, "OECD"). ${ }^{12}$ The TCJA was signed into law on December 22, 2017 (effective for tax years beginning on or after January 1,2018 ) with the objective of reducing the tax burden of US corporations, encouraging domestic investments, and increasing employment.

The TCJA eliminated the four-step graduated corporate tax rate structure with a highest rate of $35 \%$, replacing it with a flat corporate tax rate of $21 \%$. The TCJA also introduced a ceiling to the amount of deductible business interest expense in a tax year. ${ }^{13}$ It has been called the largest tax overhaul since the Reagan Tax Reforms in 1981 and 1986; the US now joins the lowest taxed group among OECD members.

The reduction in corporate tax rate also decreases tax savings on pension contributions. According to 26 U.S. Code $\$ 404(a)$, $\$ 6072(a)$, and $\$ 6081(b)$, contributions to qualified DB plans are generally deductible from taxable income. In addition, a grace period of up to ten and half

\footnotetext{
${ }^{12}$ The OECD Tax database: https://stats.oecd.org/Index.aspx?QueryId=78166\#

${ }^{13}$ The upper limit for interest expense is equal to the sum of (1) business interest income for the taxable year; (2) $30 \%$ of the adjusted taxable income of the taxpayer for the taxable year; and (3) the floor plan financing interest expense for the taxable year. Any amount of interest expense exceeding the above limit is not allowed to be deducted in the taxable year and will be carried forward for up to five years.
} 
months is granted to allow firms to make contributions after the taxable year-end, but deduct from taxable income earned during that tax year. So a firm with fiscal year ending on December 31, 2017, for example, still has a window of opportunity: any contributions made before September 15,2018 , can be deducted at the higher ("old") rate. This grace period was crucial to enabling December-year end firms to obtain tax deductions on accelerated pension contributions at the old rate, and hence forms a key part of our research design.

Drivers of increased contributions in the window of opportunity: Do derisking concerns matter?

Anecdotes, practitioner surveys (e.g., Goldman Sachs 2018), and academic evidence (GLV) indicates a surge in pension contributions in the pre-TCJA window of opportunity, presumably from sponsors accelerating future contributions so as to claim deductions at the pre-TCJA tax rate of $35 \%$. We do not, however, expect this contribution response to be uniform in the cross-section; sponsors that derive greater benefits from accelerating contributions will be more likely to do so.

We posit that the ultimate objective of derisking pension plans drove accelerated contributions from many sponsors. Accordingly, we identify plan- and sponsor-specific factors that create a greater economic burden from pension contributions; we expect these firms to have correspondingly greater motivation to accelerate contributions so as to derisk their pensions.

First, we expect sponsors with relatively poorly-funded plans to accelerate contributions more, for multiple reasons. From a taxation perspective, pension contributions are deductible only up to a limit, based on funding level—sponsors cannot continue to claim tax deductions for contributions made to fully- (or over-) funded plans. ${ }^{14}$ Furthermore, assets once contributed are costly to withdraw, and overfunded plans can trigger union demands for benefit increases.

\footnotetext{
${ }^{14}$ According to 26 U.S. Code $\S 404$ (o), in general, contributions are deductible if the amount of such contributions do not exceed the excess of the sum of funding target, target normal cost and the "cushion amount", over the actuarial value of plan assets. The cushion amount is the sum of 50\% of the funding target and any amount by which the funding target would increase if increases in compensation are expected to occur.
} 
Importantly, from a pension risk perspective, poorly-funded plans generate larger mandatory contributions from federal pension laws; these plans can hence pose a substantial drain on operating cash flows (Rauh, 2006). The burden from underfunded plans is even greater once other carrying costs are considered: all tax-qualified plans (i.e., to which contributions are tax deductible) are required to pay yearly insurance premiums to the PBGC, which are partly based on their funding deficit. These insurance premia have been rising considerably in recent years, more than doubling since 2009. ${ }^{15}$ Our first hypothesis follows:

Hypothesis 1 (H1): Firms with lower pension funding status increase voluntary contributions to $D B$ plans in the TCJA period more than firms with higher pension funding status.

DB plans can also be unpredictable in their cash demands, as funding ratios change yearon-year due to market performance, changing interest rates, and shifts in other actuarial assumptions. CFOs often describe DB plans as a "volatile debt" that they are forced to carry on their balance sheets (Wall Street Journal, 2018), which "consistently defies planning and budgeting exercises"(Buck Consultants, 2020), Some plans are more subject to this uncertainty than others in plans with more active employees, the eventual benefit is still subject to unpredictable fluctuations in future salary increases, retirement ages, disability rates, form of benefit elected, etc., whereas with inactive beneficiaries (i.e., retired or terminated employees) the benefit has already been "defined" to a large extent. Plans with more active participants also have a longer duration, making the obligation more sensitive to any fluctuation in interest rates. While such plans may not

\footnotetext{
${ }^{15}$ The PBGC insurance premium consists of: (i) a variable-rate premium determined by plan funded status and (ii) a flat-rate premium based on the number of participants. Variable-rate premiums have been rising from $3.4 \%$ on any unfunded benefits in 2017 to 3.8\% (2018), 4.3\% (2019), and 4.5\% (2020). Variable-rate premiums are capped at $\$ 517$ times the number of participants in 2017, but the cap rate rises to $\$ 541$ in 2019 . Meanwhile, flat-rate premiums are up from $\$ 69$ per participant in 2017 to $\$ 74$ (2018), $\$ 80$ (2019), and $\$ 83$ (2020). For more information, see: Pension Benefit Guarantee Corp., 2019 Premium Rates, Source: Pension Benefit Guarantee Corp. (PBGC), Premium Rates, https://www.pbgc.gov/prac/prem/premium-rates
} 
need cash immediately to fund benefit payouts, by accelerating contributions to reach near-funding they could also derive greater benefits of reducing the volatility from uncertain future funding requirements. Our second prediction follows:

Hypothesis 2 (H2): Firms with relatively more active participants increase voluntary contributions to DB plans in the TCJA period more than firms with lesser active participants.

We consider a third plan-level characteristic: how many participants are supported by each firm's plans. The insurance premia that sponsors pay to the PBGC consists of two parts, one based on the funding deficit ("variable-rate" premium) and one based on the number of participants ("fixed-rate" premium). Plans with more participants, therefore, incur a larger cost to simply maintain their plans, relative to the benefits actually paid out. These plans could have particular incentives to improve funding so as to then settle the plan liability in a PRT transaction - which then removes PBGC protection and in turn, premiums (CFO Research, 2018; Prudential, 2019). Our third prediction follows:

Hypothesis 3 (H3): Firms with higher flat-rate premiums increase voluntary contributions to DB plans in the TCJA period more than firms with lower flat-rate premiums.

Moving to sponsor-level characteristics, even amongst DB pension sponsors, large and fluctuating cash contribution requirements can be costlier for some sponsors than for others. We expect sponsors with more competing demands on their cash flows to be more strongly motivated to derisk pensions when the opportunity presents itself. Accordingly, we examine competing demands along two dimensions: investment opportunities and dividend policy.

A robust literature examines how (mandatory) pension contributions affect investment in operating projects (e.g. Rauh, 2006; Campbell et al., 2012; Bakke and Whited, 2012; Dambra, 2018), and concludes that mandatory pension contributions do displace investments, particularly for firms with underfunded plans. As a result, firms with stronger investment opportunities could be particularly driven to make a larger one-time pension contribution. If profitable investment 
decisions are constrained by pension funding requirements, exploiting the TCJA's window of opportunity allows such a constrained firm to maximize current tax savings, while also progress with derisking (either through asset allocation shifts or pension risk transfer). This then allows the firm to proceed with its investment agenda relatively unhampered by pension funding requirements for the near- to medium-term. ${ }^{16}$ To that extent, we would expect firms with greater investment opportunities to be more motivated to derisk; our prediction follows: ${ }^{17}$

Hypothesis 4 (H4): Firms with greater investment opportunities increase voluntary contributions to DB plans in the TCJA period more than firms with lesser investment opportunities.

We also expect firms with a tradition of paying dividends to be similarly motivated to derisk pensions, so as to preserve the cash flows needed to maintain dividend payouts (Amir, Guan, and Oswald 2010; Anantharaman and Chuk 2018). Volatility in the cash flows required to be diverted to pensions can be especially costly to these firms. Accordingly:

Hypothesis 5 (H5): Dividend-paying firms increase voluntary contributions to DB plans in the TCJA period more than other firms.

We note that the ability to pay could act as a countervailing force to our predictions. For example, firms with many investment opportunities must choose whether to allocate current resources to pension contributions or to core investments. As a result, firms with lesser investment opportunities (or dividend commitments) might be able to make more contributions, as they have fewer competing demands on the table. This could work against our predictions, empirically.

\section{Consequences of Increased Contributions: Do firms derisk pension plans after TCJA onset?}

\footnotetext{
${ }^{16}$ Consistently, industry experts anticipate lower contributions in 2019 due to improved funding ratios from TCJA. "Contributions to corporate plans likely to be down with '17 tax law". Pensions \& Investments (March 18, 2019). Available at: https://www.pionline.com/article/20190318/PRINT/190319876/contributions-to-corporate-planslikely-to-be-down-with-17-tax-law

17 These firms must choose whether to allocate current resources to pension contributions or to core business investments. As a result, firms with lesser investment opportunities might be able to make more contributions, as they have fewer competing projects on the table; this could be a countervailing force to our prediction.
} 
Sponsors wishing to manage pension risks have a range of options; for one, they can shift plan assets away from equity towards fixed-income securities, which more naturally hedge the bond-like nature of pension obligations. In recent times, some US sponsors have resorted to more drastic, pension "risk transfer" transactions, in which the sponsor removes the liability from its books entirely, either by transferring it to an insurance company (a "settlement" or "buyout"), or by offering lump-sum payouts to beneficiaries in lieu of lifetime benefits.

A natural constraint to these derisking strategies comes from underfunding. Shifting plan assets towards bonds that are duration-matched to the benefit cash flows can immunize the plan from interest rate risk and reduce the volatility of required cash contributions; however, it also sacrifices the higher expected returns from equity investments and could necessitate more contributions from the sponsor, on average. Therefore, plans typically consider asset-liability matching only as they become well-funded or approach full funding, after which point the plan can be put into effective "hibernation" with asset-liability matching. ${ }^{18}$ Similarly, settling pension obligations with an insurer also requires transferring pension assets at least equal to the book value of the obligation settled, and typically greater than the book value, as most US settlements have occurred at a premium so far. Therefore, settlements require near-full funding almost as a precondition. ${ }^{19}$ If the TCJA indeed spurs large contributions from DB sponsors and shores up funding levels, these derisking strategies could become more feasible as a result. Our final set of predictions follows:

\footnotetext{
${ }^{18}$ For example, see MassMutual Life Insurance Company (September 2019): “Key Decisions for De-Risking your Pension Plan". Available at: https://www.massmutual.com/static/path/media/institutional/is8005 082819ui_prt\%20whitepaper\%20v5 final.pdf. Another force acts in favor of shifting away from equities as plans approach full funding: reversion taxes make it costly to retrieve excess assets from an overfunded plan. So as plans approach $100 \%$ funding, the risk-reward tradeoff associated with equities becomes naturally less attractive.

${ }^{19}$ Prudential White Paper (2019). "Preparing for Pension Risk Transfer". Available at: http://pensionrisk.prudential.com/insights/prt-prep1-preparing-for-prt.php. Also see the Mercer Pension Buyout Index, available here: https://www.mercer.us/our-thinking/wealth/mercer-us-pension-buyout-index.html.
} 
Hypothesis 6 (H6): Sponsors with larger TCJA-triggered funding increases tend to decrease plan investments in risky securities more after the TCJA takes effect.

Hypothesis 7 (H7): Sponsors with larger TCJA-triggered funding increases tend to increase plan investments in safe securities more after the TCJA takes effect.

Hypothesis 8 (H8): Sponsors with larger TCJA-triggered funding increases engage in more pension risk transfer transactions after the TCJA's passage.

Prior research, however, suggests some countervailing effects. The theory of risk-shifting, as applied to DB pensions, predicts that poorly-funded plans (for whom the "PBGC put" option is more valuable) will invest more in riskier asset classes such as equities (Sharpe, 1976). The empirical evidence on this point, however, had been quite mixed. Rauh (2009), in a comprehensive examination of 10-K and Form 5500 data, documents that plan portfolios shift towards equities as plans become better-funded. ${ }^{20}$ Extrapolating Rauh (2009)'s findings into our setting, with improved funding ratios following the TCJA we would predict more risky investments, not less.

Other studies suggest that the relation between funding status and asset allocation is more nuanced. Bader (1991) argues that while moderately-funded plans might prefer to invest in equities, very well-funded plans might move away from equities and invest in safer instruments instead, so as to minimize volatility in required contributions. Accordingly, Amir and Benartzi (1999) predict and finds an inverted $\mathrm{U}$-shaped relation between funding status and allocation to equities: equity allocations increase as plans become moderately well-funded, but decline as plans become very well-funded. As the risk-returns tradeoffs associated with equities become naturally less attractive as plans approach full funding, and as hibernation or PRT becomes more feasible, we could expect to see a shift away from equities at higher funding levels. Therefore, how pension asset risk

\footnotetext{
${ }^{20}$ Finding that plan portfolios move towards bonds as plans become more poorly-funded is consistent with risk management behavior, rather than risk-shifting behavior (Rauh 2009).
} 
changes post-TCJA - whether we will see a shift towards equities or away from them - ultimately begs empirical examination.

\section{RESEARCH DESIGN}

\section{Determinants of Contributions in the TCJA window of opportunity}

We examine the contribution response to the TCJA with the following regression model:

$$
\begin{aligned}
& \text { Voluntary Contribution }_{i, t} \\
& \qquad \begin{array}{l}
=\alpha+\beta_{1} * \text { TCJA } A_{i, t}+\beta_{2} * \text { FundRatio }_{-} 5500_{i, t}+\beta_{3} * \text { ActivePBO }_{i, t}+\beta_{4} \\
\\
\quad * \text { Size }_{i, t}+\beta_{5} * \text { Lev }_{i, t-1}+\beta_{6} * \text { ROA }_{i, t}+\beta_{7} * P P E_{i, t}+\beta_{8} * \text { SaleGrowth }_{i, t} \\
\quad+\text { Firm FE }+ \text { Year FE }+\epsilon_{i, t}
\end{array}
\end{aligned}
$$

To examine whether derisking concerns drive the contribution response, we augment

Model (1) with interactions flagging the firms with stronger incentives to derisk:

$$
\begin{aligned}
& \text { Voluntary Contribution }_{i, t} \\
& =\alpha+\beta_{1} * T C J A_{i, t}+\beta_{2} * H i g h_{i, t}+\beta_{3} * T C J A_{i, t} * H i g h_{i, t}+\beta_{4} \\
& * \text { FundRatio_5500 } 50_{i, t}+\beta_{5} * \text { ActivePBO }_{i, t}+\beta_{6} * \text { Size }_{i, t}+\beta_{7} * \text { Lev }_{i, t-1}+\beta_{8} \\
& * R O A_{i, t}+\beta_{9} * P P E_{i, t}+\beta_{10} * \text { SaleGrowt }_{i, t}+\text { Firm FE }+ \text { Year FE }+\epsilon_{i, t}
\end{aligned}
$$

The dependent variable is voluntary contributions for the plan year, scaled by lagged total assets, multiplied by 100 for ease of interpretation. We rely on Form 5500s for data on voluntary contributions. We use Form 5500s rather than the Compustat Pension dataset, which compiles sponsoring firm-level pension disclosures from SEC filings, for two reasons. First, the Form 5500 breaks total contributions into mandatory and voluntary for each reported plan year, whereas this disclosure is not required in SEC filings. Our interest is specifically in the voluntary contribution, which captures discretionary funding choices. Second, Form 5500s, which were also designed to satisfy reporting requirements under the Internal Revenue Code, allow us to cleanly isolate contributions that are tax-deductible - the salient construct in our study. As our analysis is at the firm-level, we aggregate plan-level Form 5500 filings to the sponsoring firm-level. 
$T C J A$ is an indicator variable equal to one for firm-year observations with a year-end falling in the "TCJA period", and zero otherwise. At an intuitive level, the "TCJA period" represents our attempt to define the window of opportunity that sponsors had to maximize tax deductions: the period starting from the TCJA's signing into law, and ending when its lower tax rate becomes effective. To be included in the window, therefore, firm-years must meet two criteria: first, there must be at least a day after the TCJA's passage for the sponsor to make contributions in response; and second, any contributions that will only be deducted at the lower ("new") rate must not be included. Complicating the definition of this window is a feature unique to this setting - sponsors can make contributions (and file Form 5500s) up to ten and half months after the tax year ends, but still deduct those contributions at the tax rate applicable to that tax year. ${ }^{21}$

As the TCJA was signed into law on December $22^{\text {nd }}, 2017$, sponsors with fiscal year ending on March 31 ${ }^{\text {st }}, 2017$ can make contributions (deductible from income earned during the tax year ending on March $31^{\text {st }}, 2017$ ) up until January $15^{\text {th }}, 2018$, allowing them the time (albeit only about three weeks) to make contributions in response to the TCJA's passage-our first criterion. Hence, our window begins with fiscal year-end dates of March $31^{\text {st }}, 2017 .{ }^{22}$ As the TCJA is effective for fiscal years beginning on and after January $1^{\text {st }}, 2018$ (i.e., ending on December $31^{\text {st }}, 2018$ ), our window ends right before, at the fiscal year-end of November $30^{\text {th }}, 2018$, to meet our second criterion, as all contributions made by these firms still qualify for deduction at the old rate. Fiscal years ending December 31, 2018 and onwards, though, are not included in the window, as the TCJA's reduced tax rate becomes applicable. Therefore, fiscal years ending March 31 $1^{\text {st }}, 2017$ to

\footnotetext{
${ }^{21}$ Generally, this grace period is nine and half months after the year-end. However, the grace period is eight and half months for firms with a taxable year ending on December 31, and ten and half months for firms with a taxable year ending on June 30 (see 26 U.S. Code $\S$ 404(a)(6), § 6072(a), and $\S 6081(\mathrm{~b})$ ).

22 According to 26 U.S. Code $\S 441$ (b), generally, tax year of a public-traded U.S. firm is the same as its annual accounting reporting period, i.e. the fiscal year. Therefore, we use "fiscal year" and "tax year" interchangeably.
} 
November $30^{\text {th }}$, 2018 comprise our window of opportunity, which we denote the "TCJA period" (Figure 1 illustrates). By completely spanning the period in which firms can respond to the TCJA with voluntary contributions that still qualify for deduction at the old tax rate, we ensure a comprehensive estimate of TCJA-triggered contributions.

We identify firms' response to TCJA by comparing voluntary contributions made in the TCJA period with voluntary contributions made in a "control" period before its passage, which we denote the "pre-TCJA period". A positive and significant coefficient on TCJA $\left(\beta_{1}\right)$ in Model (1) would indicate that voluntary pension funding increased in the TCJA period, presumably to maximize tax benefits before its effective date. Positive and significant coefficients on the TCJA*High $\left(\beta_{3}\right)$ interactions in Model (1a) would indicate a stronger TCJA-triggered contribution response from firms we identify as being particularly driven to derisk.

We control for key pension- and firm-level fundamentals that could drive contribution behavior. We control for pension funded status (FundRatio_5500), defined as total US pension assets before current year pension contributions divided by total US pension liabilities; we expect well-funded firms to contribute less. We also control for obligations attributed to active participants (ActivePBO). Both of these controls are obtained by aggregating Form 5500 data to the firm-level. Moving to sponsoring firm fundamentals, we control for firm size (Size), beginning leverage (Lev), return on assets $(R O A)$, asset tangibility $(P P E)$, and year-on-year sales growth (SalesGrowth). Appendix B presents detailed variable definitions.

We include firm fixed effects, to control for time invariant firm characteristics, and year fixed effects to control for any aggregate time trends in contributions. We view the year fixed 
effects as important in helping us to separate the effects of the TCJA from other ongoing trends or events specific to 2017 and 2018. ${ }^{23}$ We cluster standard errors at firm level.

\section{Consequences of Contributions - Pension Asset Allocations}

To examine whether firms more impacted by the TCJA tend to shift plan asset allocations towards safer investments, we estimate the following model:

$$
\begin{aligned}
& \Delta \% R I S K Y_{i, t} \text { or } \Delta \% S A F E_{i, t} \\
& =\alpha+\beta_{1} * \Delta \text { FundRatio }_{-} \text {TCJA }+\beta_{2} * \text { FundRatio }_{i, t} \\
& +\beta_{3} * \text { FundRatio }_{i, t}{ }^{2}+\beta_{4} * \text { ARR }_{i, t}+\beta_{5} * \text { ARR }_{i, t-1}+\beta_{6} * \text { DiscountRate }_{i, t} \\
& +\beta_{7} * \text { ROCI }_{i, t}+\beta_{8} * \% \text { Risky }_{i, t-2}\left(\text { or, } \% \text { Safe } e_{i, t-2}\right)+\beta_{9} * \text { Horizon }_{i, t}+\beta_{10} \\
& * \text { TaxBill }_{i, t}+\beta_{11} * \text { Size }_{i, t}+\beta_{12} * \text { Lev }_{i, t-1}+\beta_{13} * \text { Dividend }_{i, t}+\beta_{14} * S D C F_{i, t} \\
& +\beta_{15} * \text { MarketReturn }_{i, t}+\epsilon_{i, t}
\end{aligned}
$$

Our analysis continues to be at the sponsoring firm-level, and for Eq. (2) all variables are obtained from SEC filings via Compustat. The dependent variable is alternatively the percentage of plan assets invested in risky securities (\%RISKY), or in safe securities (\%SAFE).

If the TCJA indeed generated a surge in DB contributions, a direct consequence is improvement in funding status. Therefore, we gauge responsiveness to the TCJA by the improvement in funding status between the period preceding TCJA signing, and the period after TCJA goes into effect ( $\triangle$ FundRatio_TCJA). Consider a sponsor with fiscal year ending on December $31^{\text {st }}$, for example; we calculate funding ratio on December $31^{\text {st }}, 2018$ (right after the "TCJA period" window ends) minus funding ratio on December 31 ${ }^{\text {st }}$, 2016 (the last fiscal year before TCJA passage). Hypothesis 6 (Hypothesis 7) predicts $\beta_{1}$ to be significantly negative (positive) with \%RISKY (\%SAFE) as the dependent variable.

\footnotetext{
${ }^{23}$ The year fixed effects become estimable in a model containing TCJA only because our compilation of the window of opportunity (fiscal years ending March 31, 2017 to November 30, 2018) yields multiple observations with, $T C J A=1$ for some firms. With a shorter window, the year effects would be collinear with TCJA.
} 
As $\triangle$ FundRatio_TCJA is set up specifically to measure changes over the TCJA period, we estimate this model only on one cross-section of data, i.e., the post-TCJA period, which comprises fiscal years ending from December $31^{\text {st }}, 2018$ to November $30^{\text {th }}, 2019$ (please see Figure 1). Our objective with this test, therefore, is to examine whether asset allocations shift post-TCJA as a function of how strongly funding surged in the TCJA window of opportunity. To the extent to which the TCJA-triggered funding surge made derisking feasible, we would expect firms with a stronger funding improvement to unwind equity allocations; however, it remains an open question whether funding improves sufficiently to bring that about.

We control for known determinants of asset allocation from Amir et al. (2010; Anantharaman and Chuk (2018), Anantharaman and Lee (2014), Rauh (2009). We incorporate the level of funding status (FundRatio) and its square (FundRatio ${ }^{2}$ ) to account for any nonlinear relations between asset allocation and funding status, shown in prior work. We also control for plan horizon (Horizon), estimated by inverting the relation between the $\mathrm{PBO}$ and $\mathrm{ABO}$, as plans with younger participants have longer investment horizon and may find it optimal to invest in equity securities. ${ }^{24} \mathrm{We}$ include contemporaneous and past actual rates of return on pension assets $\left(A R R_{i, t}, A R R_{i, t-1}\right)$ to control for passive movements in equity allocations arising from failure to rebalance period-by-period (Rauh 2009), supplemented by the broad-based performance of global equity markets with returns to the S\&P Global Broad Market Index for equities (MarketReturn). We also control for the level of allocation to risky or safe assets at the beginning of the TCJA

\footnotetext{
${ }^{24}$ Horizon is a more indirect estimate of the plan's age profile compared to ActivePBO, which we use in Eq (1) and which directly captures the proportion of the obligation owed to active participants. In Eq. (1), we use Form 5500 data, allowing the use of ActivePBO. In contrast, Eq. (2) is based entirely on sponsoring firm-level data extracted from 10-Ks via Compustat, since asset allocation data on Form 5500s are too crude and noisy to be usable. Firmlevel pension disclosures allow only crude estimates of pension horizon, as reviewed in Blankley, Hong, and Roland (2018).
} 
window ( $\% R i s k y_{i, t-2}$ or $\% S a f e_{i, t-2}$ ), as firms with a higher equity allocation will have more scope and greater need to derisk.

Moving from pension characteristics to firm characteristics, we include the taxpaying status of the sponsor (TaxBill), defined as federal tax expense before pension contribution deductions, as Black (1980) and Tepper (1981) predict that taxpaying sponsors invest more in bonds (Amir, Guan, and Oswald 2010; Anantharaman and Chuk 2018; Rauh 2009). Larger sponsors could have more diversified investment portfolios (Size). Some firms could have particular incentives to minimize the volatility of plan funding status (and hence of contribution requirements) - highly leveraged firms (Lev), firms with a tradition of paying dividends (Dividend), and firms with inherently volatile operating cash flows ( $S D C F$, the standard deviation of operating cash flows). The actuarial assumptions affecting pension liability measurement (the discount rate -- DiscountRate $e_{i, t}$, and the rate of compensation increase -- $\left.R O C I_{i, t}\right)$ help to control for changes in funding status that are unrelated to sponsor contributions in the TCJA window.

\section{DATA AND SUMMARY STATISTICS}

\section{Sample Selection and Data Description}

We obtain qualified pension plan data for Eq. (1)-(1a) from the Form 5500 dataset, compiled by the US Department of Labor ("DOL") from US plan filings. We obtain from Form 5500s the mandatory contributions (i.e., calculated by predetermined formulae so as to maintain minimum funding levels set by federal pension regulation) and voluntary contributions (i.e., those in excess of mandatory contributions, made at the discretion of the sponsor) separately. Form 5500s are the only source for these data, as sponsors only report total contributions (without distinguishing mandatory and voluntary) on SEC filings. Another advantage of Form 5500 data is that sponsors are not required to separate US from international plans, nor qualified from non- 
qualified plans on SEC filings. Contributions to non-qualified plans are not tax deductible, and contributions to international plans are presumably not (directly) influenced by the TCJA. We restrict our sample to qualified ERISA pension plans with at least 100 participants at the beginning of the 2017 plan year, and to plans not terminated before the TCJA was signed into law (i.e., 12/22/2017). Obtaining sponsoring firm fundamentals necessitates matching the Form 5500 dataset to Compustat. The two datasets lack a common identifier, as a result of which we employ a multistep process (detailed in Table 1) to obtain as complete a match as possible.

As shown in Table 1, Panel A, our sample begins with 47,704 firm-year observations from the Compustat Fundamentals database, from 2013 to 2018. We restrict our sample to firms that are either incorporated or headquartered in the US, as firms that are neither incorporated nor headquartered in the US may have different tax planning strategies. Removing (1) observations with non-positive or missing total assets, or missing sales; (2) firms without observations in the TCJA period; (3) firms that cannot be matched to ERISA-qualified pension plans; (4) observations with missing data required for main analyses, leaves us with 3,885 firm-year observations from 799 unique firms for tests on determinants of voluntary contributions. As Compustat Pensions has a "universe" of about 1200 US pension sponsors, our sample has reasonable coverage despite the challenges of hand-matching Form 5500s to Compustat. ${ }^{25}$

Data for pension-related variables for asset allocation tests [Eq. (2)] are obtained from the Compustat Pension Annual dataset. We use solely Compustat data for these tests because asset allocation on Form 5500s is crude, with most sponsors classifying a large proportion of assets into ambiguous categories from which users cannot infer whether they are equity, fixed income, real

\footnotetext{
${ }^{25}$ Some of these US pension sponsors on Compustat could have only international pension plans (this is not identifiable in a machine-readable way), hence the applicable Compustat universe is most likely less than 1200.
} 
estate, or other asset classes whose risk-return characteristics are understood. ${ }^{26}$ Furthermore, most Form 5500s for plan years in the post-TCJA period are not yet available.

Table 1, Panel B outlines sample selection for asset allocation tests. We begin with 4,669 firm-year observations from the 799 firms included in the sample for Eq. (1)-(1a), from 2013 to 2019. We remove (1) observations with fiscal year-end falling in the TCJA period (i.e., from March 31 $1^{\text {st }}, 2017$ to November 30 $\left.{ }^{\text {th }}, 2018\right)$; (2) observations that are missing data needed for Eq. (2); and (3) firms that do not have post-TCJA observations. This leaves us with 417 unique firms for which we can relate funding changes over the TCJA window to asset allocation shifts postTCJA, as laid out in Eq. (2).

Table 2, Panel A reports descriptive statistics of variables used in our voluntary contribution analyses [Eq. (1)-(1a)]. All continuous variables are winsorized at the top and bottom 1\%. Average voluntary contributions over 2013-2018 are \$39.3 million, shifting from \$34.5 million in the pre-TCJA (control) period to $\$ 54.3$ million in the TCJA period - a statistically and economically significant increase. Total voluntary contributions made in the TCJA period amount to $\$ 51.8$ billion. Mandatory contributions are not only smaller on average but also hold fairly steady at \$9.3 million (pre-TCJA) and \$10.9 million (TCJA).

The average funded status reported on Form 5500s is $112 \%$, and about $50 \%$ of the sample has overfunded plans; note however that the obligation (and hence funding ratio) on the Form 5500 is calculated differently from that calculated for financial reporting purposes on the 10-K; we

\footnotetext{
26 Those categories, listed on Schedule H to the Form 5500, include the value of interest in "common/collective trusts", "pooled separated accounts", "master trust investment accounts", "103-12 investment entities", "registered investment companies (e.g., mutual funds)", "insurance company general account (unallocated contracts)", and "Other". Generally, these descriptors reflect the legal holding structure of the investments, rather than their riskreturn profile.
} 
denote the latter as "GAAP-based funding" for expositional clarity. ${ }^{27}$ Pension obligations owed to active participants, on average, represent $3 \%$ of total assets.

Table 2, Panel B presents descriptive statistics for the 417 firm sample used in asset allocation tests, along with comparable statistics for the pre-TCJA period, to understand longerterm trends in asset allocation. Looking at changes in asset allocation, an inflexion point is evident around the TCJA: all measures of risky investments show steep drops to the tune of $8 \%$ post-TCJA, with fixed-income investment rising commensurately. Risky investments appear to be steadily declining in the periods leading up to TCJA; however, the post-TCJA decline is about three to five times larger in magnitude. The average GAAP-based funding ratio is lower than Form 5500-based funding, and rises from $80 \%$ to $83 \%$; this is consistent with our main explanatory variable $\triangle$ FundRatio_TCJA, which shows a mean (median) increase of $3.7 \%$ (3\%); at the $25^{\text {th }}$ percentile, funding ratio remains steady, and at the $75^{\text {th }}$ percentile it increases by $7 \%$.

\section{EMPIRICAL RESULTS}

\section{TCJA-triggered contributions in the window of opportunity}

As a starting point for examining whether derisking incentives moderate voluntary contributions, we re-establish the base conclusion of GLV - that contributions surged in response to the TCJA - but (i) with our expanded sample, (ii) including the full window of opportunity to make contributions, (iii) focusing on voluntary contributions, and (iv) incorporating year fixed effects, enabled by the more complete definition of the TCJA window. We note here that while

\footnotetext{
${ }^{27}$ Pension funding on the Form 5500 is based on guidance in authoritative federal pension regulation-most recently the Pension Protection Act (2006) and the MAP-21 Act (2012), the latter of which required the 25-year average of investment-grade corporate bond yields for discounting. The funding status as reported on financial statements, in contrast, is based on guidance from Generally Accepted Accounting Principles (GAAP). Per GAAP, the pension liability for financial reporting purposes should be based on discounting at the high-quality corporate bond yield on the financial report date. As US bond yields have seen historic lows in recent years, the funding status reported in Form 5500 datasets is generally higher than GAAP-based funding in recent years. Other differences also exist besides the choice of discount rate, such as the mortality table required for estimating the length of benefit payouts.
} 
GLV's purpose was to document an economically significant contribution response; for our purposes - understanding why some firms contribute more than others, and what consequences follow for pension risk - it is essential to have a complete measure of the TCJA-triggered contribution for each firm.

To this end, we present results of estimating Eq. (1) in Table 3, Panel A. Columns (1)-(2) present estimations with only firm but no year fixed effects (consistent with GLV), while Columns (3)-(4) present estimations with firm and year fixed effects. While the coefficient on TCJA is positive and significant at the $<0.01$ level in column (1), indicating an overall increase in contributions consistent with GLV, including year fixed effects in Column (3) renders this coefficient insignificant.

GLV document that the increase in contributions occurs predominantly within taxpaying firms; accordingly, we augment Eq. (1) with an indicator for taxpaying firms and its interaction with TCJA. This yields a clearer picture: Taxpayer*TCJA is not only positive and significant at the $<0.01$ level in Column (2), but more importantly, remains virtually unchanged in Column (4) with year fixed effects. In Column (4), interestingly, the base coefficient on TCJA turns negative once the interaction term is included. Interpreting these coefficients, the negative coefficient on TCJA indicates that non-taxpaying sponsors actually decrease voluntary contributions on average, from $5.64 \%\left(\beta_{0}\right)$ to $5.41 \%\left(\beta_{0}+\beta_{1}\right)$ of total assets. Taxpaying sponsors, on the other hand, increase voluntary contributions from $5.80 \%\left(\beta_{0}+\beta_{2}\right)$ to $5.93 \%$ of total assets $\left(\beta_{0}+\beta_{1}+\beta_{2}+\beta_{3}\right)$. In sum, taxpaying firms increase voluntary contributions significantly in the TCJA window, and to the tune of $0.355 \%$ (of total assets) more than non-taxpaying firms, controlling for other determinants of voluntary contributions. 
Translating the Column (4) effects into dollar terms yields an average increase of $\$ 27.55$ million in voluntary contributions from taxpaying sponsors in the TCJA period, compared to an average decrease of $\$ 53.3$ million for non-taxpaying sponsors. Across all sponsors in our sample, this amounts to an average increase in voluntary contributions of $\$ 14.34$ million, or roughly $42 \%$ of the average pre-TCJA voluntary contribution. ${ }^{28}$ Aggregating across all sponsors yields our estimate of the total TCJA-triggered contribution for our sample $-\$ 13.7$ billion.

While these estimates come from Column (4), the model in Column (2) is more comparable to GLV, with its use of firm but not year fixed effects. The average increase in voluntary contributions across all sponsors in the TCJA period, from that model, works out to a much larger $\$ 39.72$ million, or $115 \%$ of the pre-TCJA voluntary contribution. Aggregating across all sponsors yields total TCJA-triggered contributions of $\$ 37.9$ billion. ${ }^{29}$ Compared to GLV's estimate of $\$ 6.3$ $\$ 7.9$ billion, our expansion of the sample and inclusion of the full TCJA window does, therefore, make an economically significant difference to estimates of the TCJA's impact. However, we believe that the $\$ 13.7$ billion estimate from Column (4) is more cleanly attributable specifically to the TCJA.

In Table 3, Panel B, we present estimations of a placebo test, wherein we rerun Eq. (1) but with the dependent variable as mandatory contributions, which are predetermined by formulae established by federal pension regulation. Consistent with expectation, we observe no significant

\footnotetext{
28 The average increase of $\$ 14.34$ million for Column (6) is the total estimate of TCJA-triggered voluntary contributions divided by the total number of observations (both taxpaying and non-taxpaying) in the TCJA period [ $\$ 13.7$ billion/ $(799+156)=\$ 14.34$ million]. Similar calculations for Column (3) yield $\$ 39.72$ million.

${ }^{29} \mathrm{We}$ obtain these estimates as follows: Using the model with firm and year fixed effects in Column (4), for taxpaying sponsors, $\left(\beta_{1}+\beta_{3}\right)$ percent * pre-TCJA mean of $\$ 22.043$ billion of total assets yields an average increase of $\$ 27.55$ million. For non-taxpaying sponsors, $\left(\beta_{1}\right)$ percent $*$ pre-TCJA mean of $\$ 23.174$ billion of total assets yields an average decrease of $\$ 53.3$ million. For the overall sample, this corresponds to a total estimate of TCJAtriggered voluntary contributions of \$27.55 million * 799 taxpaying observations minus $\$ 53.3$ million * 156 nontaxpaying observations $=\$ 13.7$ billion. Corresponding calculations for the model with only firm but no year fixedeffects in Column (2) yields a total estimate of $\$ 37.94$ billion in TCJA-triggered contributions.
} 
increase in mandatory contributions during the TCJA period, with an insignificant coefficient on TCJA $\left(\beta_{1}\right)$ in Column (5), and on both TCJA and on Taxpayer*TCJA in Column (6). The TCJAtriggered response, therefore, is concentrated in voluntary contributions, which we continue to use in cross-sectional tests examining derisking incentives. ${ }^{30}$

Consistent with pension funding theory and prior literature, throughout Table 3, firms with relatively poorly-funded plans (FundRatio_5500) make more voluntary contributions. Sponsors with more of their obligations owed to active participants (ActivePBO) also make more voluntary contributions. Other firm-level controls are mostly insignificant.

\section{Do derisking concerns drive voluntary contributions in the TCJA window?}

Moving to our first set of tests examining whether derisking incentives drive contributions, we present in Table 4 the results of estimating Eq. (1a), where we interact the TCJA indicator with a series of indicators flagging firms with relatively strong derisking incentives, as laid out in H1H5. Across Panels A-B, the High=l (High=0) subsample represents above-median (below-median) values of the partitioning variable, with averages presented at the bottom of Table 4 . We also augment Eq. (1a) with Taxpayer, which is positive and significant in Table 3 models.

Exploring pension plan characteristics in Panel A, we hypothesize that TCJA-triggered contributions will be greater for relatively poorly-funded plans (Columns (1)-(2)), firms with more uncertain (i.e., active) obligations (Column (3)), and firms facing higher participant-based premiums (Columns (4)-(5)). We measure relatively poorly-funded plans not only with the plan's own funding ratio (Underfund_pbo), but also with the funding deficit relative to the sponsor's

\footnotetext{
${ }^{30}$ If the surge in contributions is indeed attributable to sponsors' responding, of their own volition, to tax incentives created by TCJA, then we would expect this surge primarily in voluntary - rather than mandatory, contributions. If we had observed to the contrary that mandatory contributions also increase, that would indicate other macro shifts that we would need to investigate further. For example, contemporaneous changes in pension regulations can move contributions; macroeconomic factors such as stock market performance, inflation expectations, etc. can impact actuarial assumptions, which can in turn increase/decrease funding status reported on Form 5500s and affect required contributions.
} 
assets (Underfund_assets); sponsors with higher Underfund_assets have pension deficits that are a more economically-significant part of their corporate balance sheet. We measure the uncertainty of benefit payouts with the proportion of the obligation owed to active participants (ActivePBO); we measure premiums with the raw number of participants in the firm's plans, as well as a more direct estimate of participant-based premiums relative to sales revenues.

Coefficients on the TCJA*High interaction terms are uniformly positive and significant, largely consistent with our expectations. In terms of magnitude, sponsors with lower funding ratios and more economically-significant funding deficits increase voluntary contributions to the tune of \$35.4 million on average, and sponsors with more active obligations increase them to the tune of $\$ 32.8$ million. With premiums in Columns (4)-(5), the TCJA*High interaction term is only marginally significant when based on number of participants, but highly significant when based on the estimate of premium cost relative to the sponsor's revenues, with the higher-cost sponsors increasing contributions to the tune of $\$ 46.3$ million on average.

Poorly-funded plans will generate larger demands on cash flows in the future, and active plans generate more uncertain demands. Firms sponsoring both kinds of plans benefit more from accelerating contributions in the TCJA window, as do firms with relatively high PBGC premium costs, which can be saved by engaging in a PRT. Overall, these results are strongly suggestive of contribution responses to the TCJA being shaped by sponsors' desire to manage long-term funding risk and plan expenses.

Moving from plan-level to sponsor-level characteristics in Panel B, we hypothesize that sponsors with more competing demands on cash flows will be more eager to use the one-time opportunity from the TCJA to improve pension funding and reduce/remove pension risks. In columns (1) and (2), we examine the role of investment opportunities, by interacting with 
indicators based on market-to-book ratio and Tobin's Q, respectively. In Column (3), we interact with an indicator based on the amount of dividend paid by sponsors (Dividend). Across all three columns, we observe a consistent pattern: sponsors with greater competing demands on cash flows contribute more in the TCJA window. High-investment opportunity firms increase voluntary contributions in the TCJA window to the tune of $\$ 31$ million, and dividend-paying firms do so by $\$ 35.7$ million; we observe this response despite the demands that contributions place on internal resources. This suggests that these firms are highly motivated to maximize tax savings in the present while freeing themselves up to proceed with their investment / payout agenda in the future, unhindered by unpredictable demands for pension contributions.

\section{Do the more responsive firms derisk their plans following TCJA onset?}

We now move to our second set of tests, examining how the TCJA impacts pension asset allocations. Table 5 presents the results of estimating Eq. (2), which examines how asset allocations change post-TCJA as a function of how much plan funding shifts during the TCJA window ( $\triangle$ FundRatio_TCJA); only a single cross-section of sponsor data is used in this test. Columns (1)-(4) vary only in the asset class groupings included in the dependent variable - in Column (1), the dependent variable $(\triangle \% R I S K Y)$ is the change in percentage of pension assets invested in equity securities; Column (2) expands $\Delta \% R I S K Y$ to include real estate; Column (3) includes "other" asset classes in addition (primarily, "alternative" investments such as hedge funds and venture capital). In Column (4), the dependent variable ( $\triangle \% S A F E)$ is the change in percentage of pension assets invested in fixed-income securities, annuities, and cash / cash equivalents.

The results across columns paint a consistent picture of reduction in risky investments and a corresponding shift to safer investments. Across the broadening definitions of risky investments, a $1 \%$ (of firm assets) increase in funding ratio results in a $0.342 \%$ reduction in equities, $0.353 \%$ 
reduction in equities and real estate, and $0.402 \%$ reduction in all risky asset classes. Allocation to safer investments increases commensurately by $0.405 \%$ in Column (4), confirming that what we observe is indeed derisking rather than reallocation across various risky asset classes. For the median (mean) funding ratio increase of $3 \%(3.7 \%)$, this translates into a reduction in all risky assets of $1.2 \%(1.5 \%)$; for the $75^{\text {th }}$ percentile funding ratio increase of $7 \%$, into a reduction of $2.8 \%$. These changes are equivalent to $7 \%, 9 \%$, and $17 \%$ of one SD of risky assets.

One concern with using funding ratio changes as an explanatory variable is that the funding ratio is a composite of many different factors and inputs, which can hence change for reasons other than voluntary contributions. These other factors are primarily: (1) mandatory contributions, (2) asset returns, both of which affect the fair value of plan assets, and (3) changes in actuarial assumptions, which affect the PBO estimate. To the extent to which any of these other factors also drive changes in funding ratios over the TCJA period, our inferences on the $\triangle F$ FndRatio_TCJA $\triangle \% R I S K Y$ relation may not be attributable solely to TCJA-triggered voluntary contributions. To help attribute asset allocation shifts more clearly to TCJA-triggered voluntary contributions, we take two approaches. First, our base model includes controls for the other factors that also drive funding ratio changes: actual rates of return $\left(A R R_{i, t}, A R R_{i, t-1}\right)$, discount rates (DiscountRate $\left.{ }_{i, t}\right)$ and rates of compensation increase $\left(R O C I_{i, t}\right)$ - the two actuarial assumptions affecting PBO measurement that are disclosed on financial statements. ${ }^{31}$ Second, we modify our explanatory variable $\triangle$ FundRatio_TCJA to incorporate only voluntary contributions made in the TCJA window.

Table 5, Panel B presents these results, with the explanatory variable of interest redefined as the change in funding ratio triggered only by voluntary contributions in the TCJA window $\left(\triangle F u n d R a t i o \_T C J A \_V C\right)$. As shown in Table 2, Panel $\mathrm{B}$, the average $\triangle F$ FundRatio_TCJA_VC is

\footnotetext{
${ }^{31}$ Other actuarial assumptions also affect PBO measurement, such as retirement age, mortality/longevity, disability rates, form of benefit, etc. - but these are not required disclosure on financial statements.
} 
$16 \%$, much higher than $\triangle$ FundRatio_TCJA; this is consistent with higher discount rates and negative asset returns lowering ex post funding ratios over the TCJA window. The inferences are very similar to those from Panel A.

Among control variables, we observe a positive and significant coefficient on broad equity market returns (MarketReturn), consistent with Rauh (2009), suggesting behavioral inertia or transaction costs to rebalancing asset allocations.

\section{Placing the asset allocation findings in a broader context}

On the face of it, our findings that TCJA-triggered funding improvements lead to lower allocations to equities could be seen as contrary to Rauh (2009), who documents that as plans become better-funded, they tend to invest more in equities. Prior evidence does suggest however that non-linearities could exist in the relation between funding status and asset allocation - while moderately-funded plans could invest more in equities, very well-funded plans might not find equities as attractive. If funding ratios post-TCJA improve to a level that makes hibernation or PRT actually feasible, then we would expect to see more derisking, as we do.

Another possible explanation for the difference lies in the gulf between our time period (2013-2019) and Rauh (2009)'s (1990-2003), and in the different environment that pension sponsors operate in today. Many of the burdens associated with maintaining DB plans have, if anything, increased - e.g., mandatory funding requirements have been tightened (by the PPA 2006 and others); pension deficits are no longer allowed to be reported off-balance sheet (from SFAS 158); discount rates are at historic lows; PBGC premiums are rising. A market for settling DB pension liabilities has also developed in the US, starting from 2012, with many new insurers entering it over time - giving sponsors a feasible option for removing pension risks. As a result, it is possible that the funding - asset allocation relation itself has changed over time. 
To understand if this is the case, we rerun Eq. (2) but on a longer panel of data from 20132019, augmented in the following way:

$$
\begin{aligned}
& \Delta \% R I S K Y_{i, t} \text { or } \triangle \% S A F E_{i, t} \\
& =\alpha+\beta_{1} * \text { Post }_{-} T C J A+\beta_{2} * \Delta \text { FundRatio }_{i, t}+\beta_{3} * \text { Post }_{-} \text {TCJA } \\
& * \Delta \text { FundRatio }_{i, t}+\beta_{4} * \text { FundRatio }_{-} \text {GAAP }_{i, t} \\
& +\beta_{5} * \text { FundRatio }_{-} \text {GAAP }_{i, t}{ }^{2}+\beta_{6} * A R R_{i, t}+\beta_{7} * A R R_{i, t-1}+\beta_{8} \\
& * \text { DiscountRate }_{i, t}+\beta_{9} * \text { ROCI }_{i, t}++\beta_{10} * \% \text { Risky }_{i, t-2}\left(\text { or, } \% \text { Safe } e_{i, t-2}\right)+\beta_{11} \\
& * \text { Horizon }_{i, t}+\beta_{12} * \text { TaxBill }_{i, t}+\beta_{13} * \text { Size }_{i, t}+\beta_{14} * \text { Lev }_{i, t-1}+\beta_{15} \\
& * \text { Dividend }_{i, t}+\beta_{16} * S D C F_{i, t}+\beta_{17} * \text { MarketReturn }_{i, t}+\text { Trend }_{+} \text {Firm FE } \\
& +\epsilon_{i, t}
\end{aligned}
$$

Our main independent variable $\Delta$ FundRatio $_{i, t}$ is still calculated the same way as $\triangle$ FundRatio_TCJA, only that it now reflects the two-year change in funding ratio for the entire panel of data and not only over the TCJA window. We augment the model with a Post _ TCJA indicator flagging the time period examined in Eq. (2), and with an interaction Post_ TCJA* $\Delta$ FundRatio $_{i, t}$. The objective of this model is to determine whether the negative relation between funding improvement and risky asset allocation we observe in Table 5 is reflective of a broader shift in this relation over time, or is TCJA-specific. The results, documented in Table 6, are illuminating.

The base coefficient on $\Delta$ FundRatio, while insignificant in some models, shows significant coefficients in others in a direction consistent with Rauh (2009) - i.e., increases in funding associate with higher allocations to risky assets (Column (6)) and lower allocations to safe assets (Column (8)). The Post_TCJA indicator, however, is negative and strongly significant throughout, indicating lower risky assets to the tune of $4.5 \%-7.4 \%$ post-TCJA. The interaction Post _ TCJA* $\Delta$ FundRatio $_{i, t}$ is also negatively significant in Columns (1)-(6) but positively significant in Columns (7)-(8), indicating $0.35 \%-0.46 \%$ reduction in risky assets, with a corresponding increase in safe assets, for every $1 \%$ increase in funding over the TCJA window. Overall, these results 
indicate that the derisking we observe from Table 5 is indeed localized around the TCJA, rather than reflective of a broader trend; in other words, the TCJA appears to have acted as an inflection point of sorts for pension risk. While it is difficult to conclusively infer why, we speculate that TCJA could have delivered the equivalent of a one-two punch in favour of derisking: first by stimulating firms to make large contributions so as to maximize tax savings, and second by reducing the long-term attractiveness, from a tax perspective, of maintaining a DB plan (as the tax shield is less valuable post-TCJA), hence turning more plans in the direction of an eventual PRT transaction. We examine PRT transactions next.

\section{Do the more responsive firms engage in more PRT transactions following TCJA passage?}

Shifting pension assets towards fixed-income investments reduces many risks associated with DB pensions - as plan obligations are bond-like in nature, investing plan assets in fixedincome securities (matched by duration) can hedge interest rate risks while reducing exposure to equity markets. Whereas this approach retains the obligations within the plan, "pension risk transfer" (PRT) transactions aim to remove pension obligations from the corporate balance sheet altogether. While these transactions take many forms, two forms most commonly seen in the US are lump-sum payouts to beneficiaries and "settlements" (or "buyouts") with insurance companies.

In lump-sum payouts, the sponsor pays benefits in a lump-sum to specified participants who elect that option, where the lump-sum amount is determined by discounting the promised stream of future benefits to present value. In buyouts, the sponsor transfers pension obligations to an insurer, along with an agreed-upon amount of pension assets that reflect the buyout "price", which in the recently-developing US buyout market could be up to $110 \%$ of the PBO transferred. ${ }^{32}$

\footnotetext{
${ }^{32}$ A buyout price of $110 \%$ of PBO, e.g., means that the sponsor transfers $\$ 110$ in pension assets for every $\$ 100$ of PBO transferred. For example, please see "Preparing for Pension Risk Transfer" by Margaret G. McDonald and
} 
Most buyouts have only been of the inactive portion of pension obligations (owed to retirees or terminated participants). In both types of transactions, pension liabilities are removed from the sponsor's balance sheet, and associated risks (investment risk, longevity risk, interest rate risk, etc.) now attach to the beneficiaries (in lump-sum payouts) or to the insurer (in buyouts).

While news reports and white papers paint a picture of a recent wave of PRT transactions, we have little systematic academic evidence on them. We start by obtaining a list of PRT transactions by US sponsors compiled by the Pensions and Investments ("P\&I") magazine, a reputable source of information on and for pension funds and institutional investors. We match this list to Compustat and other data sources. Measuring firms' responsiveness to the TCJA as the change in funding ratio (TCJA period minus the pre-period), we examine whether the more TCJAresponsive firms (1) tend to undertake more PRT transactions following the TCJA's passage than they did in the period immediately before, and (2) undertake larger, more substantive transactions. Lacking a formal model for drivers of PRT transactions, our analysis is exploratory and descriptive.

In Table 7, we partition the sample into relatively high (low) change in the funding ratio between the post-TCJA and pre-TCJA period. In the group with relatively low change in funding ratio, the incidence of PRT transactions remains broadly similar before and after the passage of TCJA at $2 \%$ and $2.6 \%$ of the sample respectively, with the difference statistically insignificant. The average assets transferred in the PRT transactions, whether raw or scaled by total PBO, also remains insignificantly different over the pre- and post-TCJA periods. In contrast, within the group with relatively high change in funding ratio, the incidence of PRT transactions more than doubles, from $2.4 \%$ to $5.4 \%$ of the sample, and assets transferred increase from $0.2 \%$ to $1 \%$ of $\mathrm{PBO}$ on

Scott E. Gaul, Prudential Retirement, accessible at: https://www.institutionalinvestor.com/images/416/PRTWP004.pdf 
average for the whole sample. For those firm-years involved in a PRT transaction, average assets transferred rose from $12.2 \%$ to $28.8 \%$ of PBO. These differences are statistically significant, with the exception of raw assets transferred, where the difference is only marginally significant at $\mathrm{p}=$ $0.11 .{ }^{33}$ Overall, our preliminary exploration points to a striking conclusion: the TCJA appears to have acted as a trigger for PRT transactions.

\section{CONCLUSION}

The Tax Cuts and Jobs Act of 2017 ("TCJA") forms the largest US tax overhaul in decades. Its reduction in the corporate tax rate from $35 \%$ to $21 \%$ significantly decreases tax savings on many allowable deductions. It is intuitive that such a tax reform would affect defined-benefit (DB) pension plans, to which contributions are tax-deductible and within which assets earn returns taxfree. In this study, we examine the role played by the TCJA in altering DB pension risk; our evidence collectively points to the TCJA serving as a driver for increased "derisking" of DB pensions, through multiple channels.

In our first set of tests, we examine pre-emptive behavior in the window of opportunity after the TCJA's passage but before its reduced tax rates take effect. Gaertner, Lynch, and Vernon (2020) document early evidence of a surge in pension contributions in this window; examining these contributions deeper, we conclude that they were concentrated amongst sponsors with the strongest incentives to derisk their pensions. Specifically, sponsors facing larger and more uncertain cash contribution requirements into the future, and sponsors facing greater current burdens for PBGC premiums (that can be avoided by settling the pension with an insurer) are more likely to shore up contributions in the window of opportunity before TCJA's effective date.

\footnotetext{
${ }^{33}$ In Table OA3 of our Online Appendix, we partition the sample into groups with high, medium, and low change in funding ratio between the post-TCJA and pre-TCJA period, and find similar results.
} 
Similarly, firms with competing uses for cash such as paying dividends or investing in growth opportunities are also more likely to contribute, presumably to protect their future agendas.

In our second set of tests examining behavior after TCJA takes effect, we document that the firms that are more responsive to the TCJA also engage in more derisking of their DB plans after the TCJA. TCJA-responsive firms not only shift pension portfolios away from risky securities to safe, bond-like securities but also tend to transfer pension risks off the corporate balance sheet altogether, through lump-sum payouts to beneficiaries or settlements with insurance companies. With these tests, we identify the TCJA as a trigger - or an accelerator - of two important trends that have swept DB pensions in the US as they reach "middle age" (Buck Consultants, 2020): liability-driven investing, and a recent wave of settlements and lump-sum payouts. In combination, these trends could fundamentally reshape the DB pension landscape in the US.

Widespread media speculation and academic inquiry has been directed at the question of "who benefits" from the TCJA. That stock buybacks reached all-time highs of almost $\$ 600$ billion in the first three quarters of 2018 (Washington Post, 2018) is often quoted as evidence that stockholders primarily benefited (as opposed to employees); academic studies have also failed to find robust evidence that wages increased post-TCJA (Bennett, Thakor, and Wang 2019). To the extent to which the TCJA spurred a wave of contributions to DB plans and those funds were then invested in safe asset classes that match pension obligations, pension beneficiaries now enjoy greater benefit security, i.e., a greater likelihood that promised benefits will be paid in full. To that extent, our findings prima facie point to DB pension participants as a heretofore-overlooked (and possibly unintended) beneficiary of the TCJA. However, considering that these benefits would have been protected by PBGC insurance anyway (to some extent, even if not fully), raises the 
possibility that the PBGC itself is the ultimate beneficiary of the improved funding and subsequent derisking of US corporate pensions.

Our preliminary findings on pension risk transfer transactions add further nuance to our understanding of whether and how DB participants actually benefit. We find that the sponsors with the highest TCJA-triggered funding increases are also more likely to settle their pension obligations, either with insurers or by making lump-sum payouts to participants. Such settlements do not typically cover all beneficiaries though; they are almost exclusively targeted at retired or terminated-vested beneficiaries. If the increased funding is primarily used to fund these settlements to retired or separated employees, then these groups specifically enjoy the benefits, as opposed to those still actively employed with the companies sponsoring these plans. Moreover, pension risk transfers - whether in the form of settlements or lump-sum payments - strip participants of PBGC protection. Finally, settlements with insurance companies and direct lump-sum payments have widely differing implications for beneficiaries - the latter leaves beneficiaries responsible for managing investment risks and longevity risks. We believe that these questions - of whether, how, and which employees truly benefit from the actions documented in this study - are an important priority for future research. 


\section{APPENDIX A}

\section{Comparing GLV's Estimates and Our Estimates of TCJA-Triggered Contributions}

\begin{tabular}{|c|c|c|c|c|c|}
\hline \multirow[b]{2}{*}{$\begin{array}{l}\text { Calendar-Year- } \\
\text { End Firm }\end{array}$} & \multicolumn{4}{|c|}{ Reported in 10-Ks (GLV) } & \multirow[b]{2}{*}{$\begin{array}{c}\text { Form 5500 } \\
{[5]} \\
\text { Voluntary } \\
\text { Contributions in TCJA } \\
\text { Period } \\
\text { - Our Estimate of TCJA- } \\
\text { Triggered Contributions }\end{array}$} \\
\hline & $\begin{array}{c}{[1]} \\
\text { Expected } \\
\text { Contributions } \\
\text { for fiscal year } \\
2017 \\
\end{array}$ & $\begin{array}{c}{[2]} \\
\text { Total Annual } \\
\text { Contributions } \\
\text { Made in fiscal } \\
\text { year } 2017 \\
\end{array}$ & $\begin{array}{c}{[3]=[2]-[1]} \\
\text { Unexpected } \\
\text { Contributions in } \mathbf{2 0 1 7} \\
- \text { GLV's Estimates of } \\
\text { TCJA-Triggered } \\
\text { Contributions }\end{array}$ & $\begin{array}{c}{[4]} \\
\text { Total Annual } \\
\text { Contributions } \\
\text { Made in fiscal } \\
\text { year } 2018\end{array}$ & \\
\hline $\begin{array}{l}\text { Lockheed } \\
\text { Martin Corp }\end{array}$ & $\$ 0$ million & $\$ 46$ million & $\$ 46$ million & $\$ 5,000$ million & $\$ 3896.08$ million \\
\hline PEPSICO Inc & $\$ 130$ million & $\$ 164$ million & \$34 million & $\$ 1,615$ million & $\$ 1313.97$ million \\
\hline Kellogg Co. & $\$ 26$ million & \$31 million & $\$ 5$ million & $\$ 270$ million & $\$ 229.63$ million \\
\hline
\end{tabular}

We compare our estimates of TCJA-triggered contributions with GLV's. GLV's measure of TCJA-triggered contributions is the total annual pension contribution minus the corresponding expected contribution reported in the prior year's financial statements, i.e. total annual pension contribution made in 2017 minus the expected contribution reported in 2016 10-K. As a calendar year-end firm can make pension contributions until September 15" 2018 (the "grace period") and deduct those contributions from 2017's taxable income, GLV's estimates potentially omit TCJA-triggered contributions made in 2018. We provide three examples above to illustrate this point.

Column [1] shows the expected contributions for 2017 fiscal year, which are reported in 2016 financial statements (10-Ks). Column [2] lists total annual pension contributions made by the sponsor in fiscal year 2017, as found in the 2017 10-Ks. Column [3] is difference between column [2] and column [1], representing GLV's estimates of TCJA-triggered contributions.

Column [4] shows annual pension contributions made in fiscal year 2018, reported on the 2018 10-K. Some of these contributions were made within the 2017 grace period and would hence have been deductible under the pre-TCJA tax rate; however, they are excluded from GLV's estimate of TCJA-triggered contributions. Finally, column [5] is our measure of TJCA-triggered contributions using voluntary contributions obtained from the Form 5500 for the TCJA period, as defined in Figure 1. 
Lockheed Martin Corp., our first example, expected no contributions to their pension plans in $2017 .{ }^{34}$ "There were no material contributions to our qualified defined benefit pension plans during 2017. We will make contributions of $\$ 5.0$ billion to our qualified defined benefit pension plans in 2018, including required and discretionary contributions”, from Lockheed Martin's 2017 10-K. GLV's measure omits the voluntary portion of this $\$ 5$ billion contribution made in 2018, while our estimate (column [5]) captures the voluntary contribution that was made within the 2017 grace period and hence deductible at pre-TCJA tax rates.

Similarly, PepsiCo Inc. expected to contribute \$130 million to its pension plans in 2017 (column [1]). According to its 2017 10-K, actual annual contributions were $\$ 164$ million (column [2]). In addition, PepsiCo states that "In February 2018, we received approval from our Board of Directors to make discretionary contributions of \$1.4 billion to our U.S. pension plans in 2018 that we intend to invest in fixed income securities.” Under GLV's estimate, TCJA-triggered contributions are \$34 million (column [3]) while the \$1.6 billion (column [4], which includes voluntary as well as mandatory contributions), is excluded, even though it was largely contributed within the 2017 grace period and hence deductible at pre-TCJA tax rates.

Kellogg Co. expected to contribute \$26 million for 2017 (column [1]) but contributed \$31 million in 2017 (column [2]). Applying GLV's approach, TCJA-triggered contributions are \$5 million (column [3]). However, in 2018, Kellogg contributed \$270 million in total to its pension plans (column [4]), much of which fell within the 2017 grace period and was hence deductible at pre-TCJA tax rates.

\footnotetext{
${ }^{34}$ In 2016 10-Ks, Lockheed Martin says "We do not plan to make contributions to our legacy pension plans in 2017 because none are required using current assumptions including investment returns on plan assets. We made \$23 million in contributions during 2016 to our newly established Sikorsky pension plan and expect to make \$45 million in contributions to this plan during 2017." The Compustat Pension dataset ignores the \$45 million expected contributions to Sikorsky pension plan and records 0 expected contribution. In a further complication to using Compustat Pension data, therefore, the $\$ 46$ million unexpected contribution in column [2] is not really "unexpected".
} 


\section{APPENDIX B}

\section{Variable Definitions for Main Analyses}

\begin{tabular}{|c|c|c|}
\hline Variable & Description & Source \\
\hline \multicolumn{3}{|l|}{$\underline{\text { Dependent Variables }}$} \\
\hline Voluntary & Voluntary contributions aggregated at firm-level and scaled by lagged (firm) assets. & $\begin{array}{l}\text { Form 5500: Schedule SB, } \\
\text { line } 38 a\end{array}$ \\
\hline Mandatory & $\begin{array}{l}\text { Mandatory contributions made after the carryover and prefunding balances elected for use to offset } \\
\text { funding requirements (aggregated at firm level) and scaled by lagged (firm) assets. }\end{array}$ & $\begin{array}{l}\text { Form 5500: Schedule SB, } \\
\text { line } 36\end{array}$ \\
\hline Total Contribution & Total contributions aggregated at firm-level and scaled by lagged (firm) assets. & $\begin{array}{l}\text { Form 5500: Schedule SB, } \\
\text { line } 37\end{array}$ \\
\hline$\Delta$ (\%Equity) & Two-year change in percentage of pension assets invested in equity securities. & Compustat Pension: pnate \\
\hline $\begin{array}{l}\Delta(\% \text { Equity } \\
+\% \text { RealEstate })\end{array}$ & Two-year change in percentage of pension assets invested in equity securities and real estate. & $\begin{array}{l}\text { Compustat Pension: pnate, } \\
\text { pnatr }\end{array}$ \\
\hline $\begin{array}{l}\Delta(\% \text { Equity }+\% \text { RealEstate } \\
+\% \text { Other })\end{array}$ & $\begin{array}{l}\text { Two-year change in percentage of pension assets invested in equity securities, real estate, and other } \\
\text { assets. }\end{array}$ & $\begin{array}{l}\text { Compustat Pension: pnate, } \\
\text { pnatr, pnato }\end{array}$ \\
\hline$\Delta(\%$ FixedIncome $)$ & Two-year change in percentage of pension assets invested in fixed income securities. & Compustat Pension: pnatd \\
\hline \multicolumn{3}{|l|}{ Independent Variables } \\
\hline TCJA & $\begin{array}{l}\text { An indicator variable equal to } 1 \text { in fiscal years ending on } 03 / 31 / 2017 \text { to } 11 / 30 / 2018 \text {, and equal to } 0 \\
\text { in fiscal years ending before } 03 / 31 / 2017 \text {. }\end{array}$ & N/A \\
\hline Taxpayer & $\begin{array}{l}\text { An indicator variable equal to } 1(0) \text { when federal tax expense plus total contributions reported on } \\
\text { Form } 5500 \text { multiplying by highest statutory tax rate before the TCJA takes effect }(35 \%) \text { is greater } \\
\text { (smaller) than zero. }\end{array}$ & $\begin{array}{l}\text { Compustat Fundamentals: } \\
\text { txfed; Form 5500: } \\
\text { Schedule SB, line } 37\end{array}$ \\
\hline FundRatio_5500 & $\begin{array}{l}\text { The actuarial value of total U.S. pension assets divided by total U.S. pension obligations under } \\
\text { Form } 5500 \text {. }\end{array}$ & $\begin{array}{l}\text { Form 5500: Schedule } S B \text {, } \\
\text { line } 2 b \text { and } 3 d(3)\end{array}$ \\
\hline ActivePBO & $\begin{array}{l}\text { A continuous variable calculated as pension obligations owed to active participants from all } \\
\text { qualified plans scaled by lagged (firm) assets. }\end{array}$ & $\begin{array}{l}\text { Form 5500: Schedule } S B \text {, } \\
\text { line } 3 c(3)\end{array}$ \\
\hline Beginning Firm Assets & Dollar value of total firm assets at the beginning of a fiscal year. & $\begin{array}{l}\text { Compustat Fundamentals: } \\
\text { at }\end{array}$ \\
\hline Size & Natural logarithm of beginning (firm) assets. & $\begin{array}{l}\text { Compustat Fundamentals: } \\
\text { at }\end{array}$ \\
\hline Lev & $\begin{array}{l}\text { The beginning leverage, calculated as the sum of long-term debt and debt in current liabilities } \\
\text { scaled by lagged (firm) assets. }\end{array}$ & $\begin{array}{l}\text { Compustat Fundamentals: } \\
d l t t, d l c\end{array}$ \\
\hline
\end{tabular}


ROA

PPE

SalesGrowth

Post_TCJA

FundRatio

FundRatio $^{\wedge} 2$

$\Delta$ FundRatio

$\Delta$ FundRatio_TCJA

$\Delta$ FundRatio_TCJA_VC

ARR

\section{Lag_ARR}

DiscountRate

\section{ROCI}

Lag2 (\%Equity)

Lag2 (\%Equity

$+\%$ RealEstate)

Lag2 (\%Equity

$+\%$ RealEstate+\%Others)

Lag2 (\%FixedIncome)
Pre-tax income scaled by lagged (firm) assets.

Total net amount of Property, Plant, and Equipment scaled by lagged (firm) assets.

One-year change in sales scaled by lagged (firm) assets.

An indicator variable equal to 1 in fiscal years ending on 12/31/2018 to $11 / 30 / 2019$, and equal to 0 in fiscal years ending before $03 / 31 / 2017$.

Funding ratio, measured as fair value of pension plan assets, divided by projected benefit obligation calculated using GAAP data (10-K).

FundRatio squared.

Two-year change in FundRatio.

Change in FundRatio between the post-TCJA period and two years prior (i.e. before the beginning of window of opportunity).

Change in GAAP funding ratio triggered by voluntary contributions made in the TCJA period, where voluntary contributions are compounded using discount rate on the post-TCJA 10-Ks.

Actual rate of return on plan assets.

Actual rate of return on plan assets in year $\mathrm{t}-1$.

Discount rate assumption used to determine the pension obligation on the balance sheet at the end of the year

Rate of compensation increase assumption (salary growth rate).

Percentage of pension assets invested in equity securities in year $\mathrm{t}-2$.

Percentage of pension assets invested in equity securities and real estate in year $\mathrm{t}-2$.

Percentage of pension assets invested in equity securities, real estate, and other assets in year t-2.

Percentage of pension assets invested in fixed income securities in year $\mathrm{t}-2$.
Compustat Fundamentals:

pi

Compustat Fundamentals:

ppen

Compustat Fundamentals:

sale

N/A

Compustat Pension: pplao, pplau, pbpro,

pbpru

Compustat Pension:

pplao, pplau, pbpro,

pbpru

Compustat Pension: pplao, pplau, pbpro, pbpru

Compustat Pension: pplao, pplau, pbpro,

pbpru

Compustat Pension:

pplao, pplau, pbpro,

pbpru, pbarr; Form 5500 :

Schedule SB, line $38 a$

Compustat Pension:

pbarat, pplao, pplau

Compustat Pension:

pbarat, pplao, pplau

Compustat Pension: pbarr

Compustat Pension: pprci

Compustat Pension: pnate

Compustat Pension: pnate, pnatr

Compustat Pension: pnate, pnatr, pnato

Compustat Pension: pnatd 
Horizon

TaxBill

Dividend

SDCF

MarketReturn

\section{Partitioning Variables}

Underfund_pbo

Underfund_assets

Total Participants

PBGC Flat Premiums

MTB

TobinQ
Investment horizon, measured as natural logarithm of the ratio of projected benefit obligation (PBO) to accumulated benefit obligation (ABO) divided by natural logarithm of the sum of one plus salary growth rate. Salary growth rate is replaced with 0 if missing.

Federal tax expense plus total contributions reported on 10-Ks multiplied by the highest statutory tax rate before the TCJA become in effect (35\%), scaled by lagged (firm) assets.

Dividends paid scaled by lagged (firm) assets.

Standard deviation of the ratio of operation cash flows to book value of equity for five years, ending in the current year.

24-month returns to the S\&P Global Broad Market Index for global equities.

Difference between Form 5500 obligations and actuarial value of plan assets, scaled by form 5500 obligations

For underfunded DB plans, this variable is equal to the difference between Form 5500 obligations and actuarial value of plan assets, scaled by lagged firm assets; 0 if a sponsor overfunds its DB plans.

Total number of participants in defined benefit plans sponsored by a firm.

PBGC flat-rate premiums paid by sponsors, calculated as number of total DB plan participants multiplied by PBGC premium flat rate per participant, and scaled by sales revenue.

Market value of equity + book assets - stockholders' equity scaled by lagged (firm) assets. I.e. $($ prcc_f $*$ csho + at - seq $) / a t(t-1)$

Market value of equity + book assets - book value of common equity including deferred taxes reported on $\mathrm{B} / \mathrm{S}$, scaled by lagged (firm) assets. I.e. [prcc f $* c s h o+a t-(c e q+a p)] / a t(t-1)$
Compustat Pension:

pbpro, pbpru, pbaco,

pbacu, pprci

Compustat Fundamentals: txfed; Compustat Pension:

pbec

Compustat Fundamentals:

$d v$

Compustat Fundamentals: oancf, seq

https://us.spindices.com/in dices/equity/sp-global-

bmi-usd

Form 5500: Schedule $S B$, line $2 b$ and $3 d(3)$

Form 5500: Schedule $S B$, line $2 b$ and $3 d(3)$

Form 5500: Schedule SB, line $3 a(1)$

Form 5500: Schedule SB, line $3 a(1)$; PBGC flat-rate premiums:

https://www.pbgc.gov/pra $\mathrm{c} /$ prem/premium-rates

Compustat Fundamentals: prcc f, csho, at, seq

Compustat Fundamentals: prcc_f, csho, at, ceq, ap 


\section{REFERENCES}

Amberger, Harald, and Leslie A. Robinson. 2020. The Effect of the 2017 U.S. Tax Reform on U.S. Acquisitions of Foreign Firms. SSRN Scholarly Paper. ID 3612783. Rochester, NY: Social Science Research Network.

Amir, Eli, and Shlomo Benartzi. 1999. "Accounting Recognition and the Determinants of Pension Asset Allocation." Journal of Accounting, Auditing \& Finance 14(3):321-43. doi: $10.1177 / 0148558 X 9901400309$.

Amir, Eli, Yanling Guan, and Dennis Oswald. 2010. "The Effect of Pension Accounting on Corporate Pension Asset Allocation." Review of Accounting Studies 15(2):345-66. doi: 10.1007/s11142-009-9102-y.

Anantharaman, Divya, and Elizabeth C. Chuk. 2018. "The Economic Consequences of Accounting Standards: Evidence from Risk-Taking in Pension Plans." Accounting Review 93(4):2351. doi: 10.2308/accr-51937.

Anantharaman, Divya, and Yong Gyu Lee. 2014. "Managerial Risk Taking Incentives and Corporate Pension Policy." Journal of Financial Economics 111(2):328-51. doi: 10.1016/j.jfineco.2013.10.009.

Bader, Lawrence N. 1991. The Financial Executive's Guide to Pension Plans. Salomon Brothers. Inc.: New York.

Bakke, Tor-Erik, and Toni M. Whited. 2012. "Threshold Events and Identification: A Study of Cash Shortfalls." The Journal of Finance 67(3):1083-1111. doi: 10.1111/j.15406261.2012.01742.x.

Bennett, Benjamin, Anjan V. Thakor, and Zexi Wang. 2019. Stock Repurchases and the 2017 Tax Cuts and Jobs Act. SSRN Scholarly Paper. ID 3443656. Rochester, NY: Social Science Research Network.

Black, Fischer. 1980. "The Tax Consequences of Long-Run Pension Policy." Financial Analysts Journal 36(4):21-28. doi: 10.2469/faj.v36.n4.21.

Blankley, Alan I., Philip Keejae Hong, and Kristin C. Roland. 2018. "Expected Benefit Payments and Asset Allocation in Defined Benefit Plans Post-SFAS 132(R)." Accounting Horizons 32(3):71-82. doi: 10.2308/acch-52098.

Campbell, John L., Dan S. Dhaliwal, and William C. Schwartz. 2012. "Financing Constraints and the Cost of Capital: Evidence from the Funding of Corporate Pension Plans." The Review of Financial Studies 25(3):868-912. doi: 10.1093/rfs/hhr119.

CFO Research. 2018. “Tax Law Drives Pension De-Risking Opportunity.” CFO.Com, June 25.

Cohen, Nicholas, and Manoj Viswanathan. 2019. Corporate Behavior and the Tax Cuts and Jobs Act. SSRN Scholarly Paper. ID 3449860. Rochester, NY: Social Science Research Network. 
Cooper, Russell W., and Thomas W. Ross. 2001. "Pensions: Theories of Underfunding." Labour Economics 8(6):667-89. doi: 10.1016/S0927-5371(01)00050-1.

Dambra, Michael J. 2018. "Stakeholder Conflicts and Cash Flow Shocks: Evidence from Changes in ERISA Pension Funding Rules." Accounting Review 93(1):131-59. doi: 10.2308/accr51817.

De Simone, Lisa, Charles McClure, and Bridget Stomberg. 2020. Examining the Immediate Effects of Recent Tax Law Changes on the Structure of Executive Compensation. SSRN Scholarly Paper. ID 3400877. Rochester, NY: Social Science Research Network.

Edwards, Alexander, and Michelle Hutchens. 2020. Taxes and IPO Pricing: Evidence from U.S. Tax Reform. SSRN Scholarly Paper. ID 3582280. Rochester, NY: Social Science Research Network.

Frank, Mary Margaret. 2002. "The Impact of Taxes on Corporate Defined Benefit Plan Asset Allocation." Journal of Accounting Research 40(4):1163-90. doi: 10.1111/1475679X.00085.

Frank, Mary Margaret, Jeffrey L. Hoopes, and Rebecca Lester. 2020. What Determines Where Opportunity Knocks? Political Affiliation in the Selection of Opportunity Zones. SSRN Scholarly Paper. ID 3534451. Rochester, NY: Social Science Research Network.

Gaertner, Fabio B., Daniel P. Lynch, and Mary E. Vernon. n.d. "The Effects of the Tax Cuts and Jobs Act of 2017 on Defined Benefit Pension Contributions." Contemporary Accounting Research (Upcoming). doi: https://doi.org/10.1111/1911-3846.12604.

Goldman Sachs Asset Management. 2018. "US Tax Reform Impact on Corporate Pensions." (https://www.gsam.com/content/dam/gsam/pdfs/common/en/public/articles/2017/tax_ref orm_qa_formatted_vfinal.pdf?sa=n\&rd=n).

Hanlon, Michelle, Jeffrey L. Hoopes, and Joel Slemrod. 2019. “Tax Reform Made Me Do It!” Tax Policy and the Economy 33:33-80. doi: 10.1086/703226.

Heath, Thomas. 2018. “A Year after Their Tax Cuts, How Have Corporations Spent the Windfall?" Washington Post.

Kharif, Olga, and Noah Buhayar. 2012. "Verizon Sends \$7.5 Billion in Pension Funds to Prudential." Bloomberg.Com. Retrieved April 2020 (https://www.bloomberg.com/news/articles/2012-10-17/verizon-to-move-7-5-blnpension-obligation-to-prudential).

McDonald, Margaret. 2019. "Preparing for Pension Risk Transfer.” Prudential.

Mecca, Micheal. 2020. “Losing Sleep over Pension Financials? Not These CFOs. Here’s Why. | Buck.” Https://Buck.Com, June 4. 
Rauh, Joshua D. 2006. "Investment and Financing Constraints: Evidence from the Funding of Corporate Pension Plans.” The Journal of Finance 61(1):33-71. doi: 10.1111/j.15406261.2006.00829.x.

Rauh, Joshua D. 2009. "Risk Shifting versus Risk Management: Investment Policy in Corporate Pension Plans." The Review of Financial Studies 22(7):2687-2733. doi: 10.1093/rfs/hhn068.

Sharpe, William F. 1976. "Corporate Pension Funding Policy.” Journal of Financial Economics 3(3):183-93. doi: 10.1016/0304-405X(76)90002-7.

Shumsky, Tatyana. 2018. "Companies With Newly Flush Pensions See Chance to Unload the Risk.” Wall Street Journal, October 15.

Tepper, Irwin. 1981. "Taxation and Corporate Pension Policy.” The Journal of Finance 36(1):113. doi: 10.1111/j.1540-6261.1981.tb03530.x. 
FIGURE 1

Identification of TCJA Period and Post-TCJA Period.

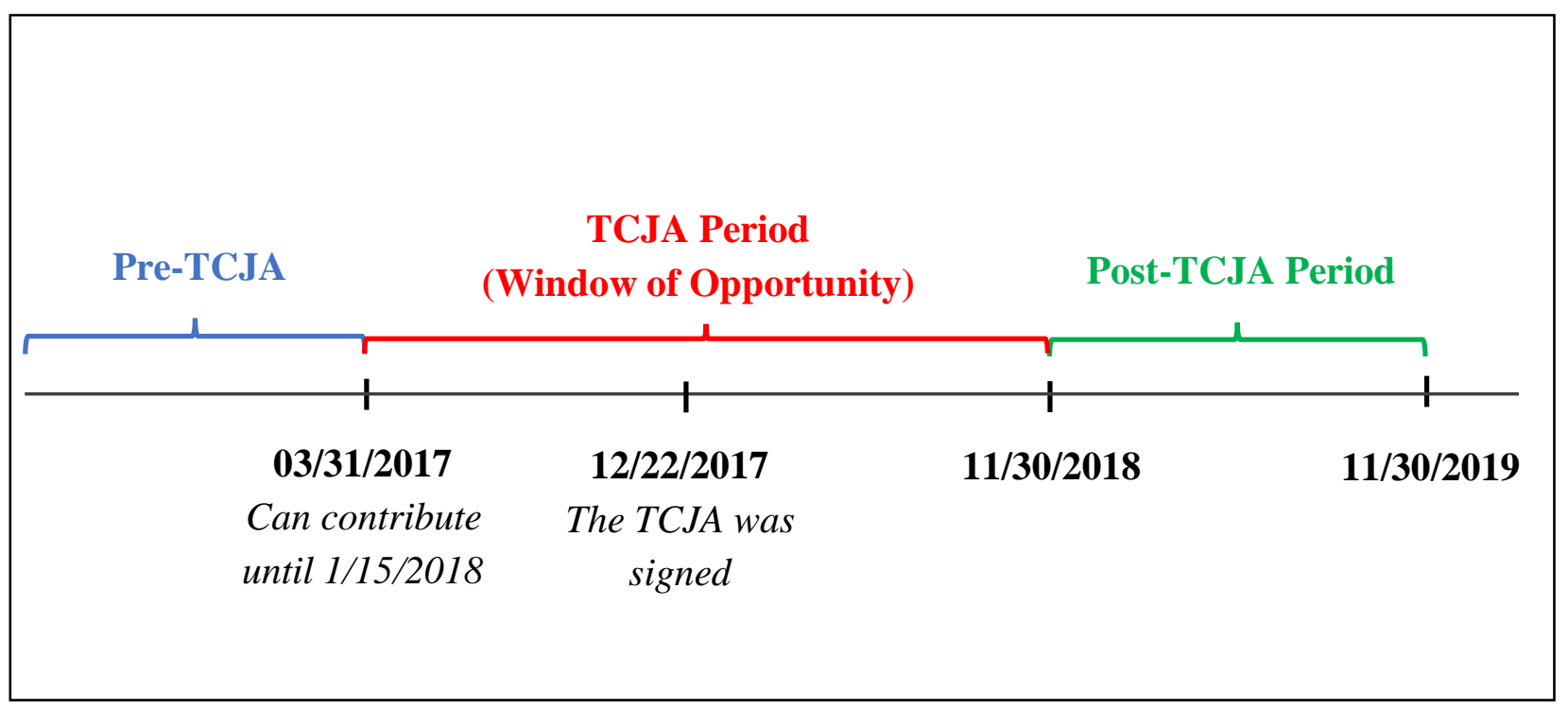

Figure 1 identifies Pre-TCJA, TCJA, and Post-TCJA periods in our analyses.

The TCJA period is the treatment period for Equation (1). As the TCJA was signed into law on December 22nd, 2017, sponsors with fiscal year ending March 31st, 2017 can make contributions (deductible from income for the tax year ending March 31st, 2017) up until January 15th, 2018, allowing them the time (albeit only about three weeks) to make contributions in response to the TCJA's passage. For illustration, a firm with fiscal year-end on February $28^{\text {th }}, 2017$ only has a grace period until December $15^{\text {th }}, 2017$ - which predates the TCJA's passage. Hence, our window of opportunity begins with fiscal year-end dates of March 31st, 2017. As the TCJA is effective for fiscal years beginning on and after January 1st, 2018 (i.e., ending on December 31st, 2018), our window of opportunity ends right before, at the fiscal year-end of November 30th, 2018, as all contributions made by these firms still qualify for deduction at the pre-TCJA tax rate. Fiscal years ending December 31, 2018 and onwards, though, are not included in the window of opportunity, as the TCJA's reduced tax rate becomes applicable. Therefore, fiscal years ending March 31st, 2017 to November 30th, 2018 comprise our treatment period for Equation (1), which we denote the "TCJA period". The Post-TCJA period, which is the treatment period for Equation (2), contains observations with fiscal years ending on December 31st, 2018 to November 30th, 2019. The TCJA' reduced tax rate becomes applicable to observations in this treatment period.

The Pre-TCJA period, which serves as a control period for both Equations (1) \& (2), contains observations with fiscal years ending before March 31st, 2017. 
TABLE 1

Sample Selection

\section{Panel A - Voluntary Contribution Tests}

Number of U.S.-based firm-year observations in Compustat Fundamentals datasets from 2013 to 2018

Less: observations with missing values in total assets and sales

Less: firms without observations in the TCJA period

Less: observations without ERISA-qualified pension plans

Less: observations with missing data required for Equation (1)

Total firm-year observations with data on contributions

Unique firms with ERISA-based pension plans for Equation (1)

\section{Panel B - Asset Allocation Tests}

Number of firm-year observations for 799 firms in Compustat Pension datasets from 2013 to 2019

Less: observations with fiscal year ending on $3 / 31 / 2017$ to $11 / 30 / 2018$

Less: observations with missing data required for Equation (2) \& (3)

Less: firms without post-TCJA observations

Total firm-year observations for Equation (3)

Unique firms with ERISA-based pension plans for Equation (2) \& (3)

Table 1 shows the sample selection process for both voluntary contribution and asset allocation tests. The voluntary contribution test requires matching between Compustat data and Form 5500 data (ERISA-qualified plans). We follow these steps for matching:

- $\quad$ First, we match the two datasets by Employer Identification Number (EIN). Unfortunately, this step does not yield a complete match as a firm may have several pension plans sponsored by different taxpaying divisions/subsidiaries that have their own EINs. Compustat lists only the EIN of the reporting entity from SEC filings.

- In a second step, we identify the sponsors of the remaining (unmatched) pension plans and match those sponsors to Compustat through an extensive manual process using D\&B Hoovers, SEC.gov, and Google.com.

- We assume that if a company is a subsidiary of a Compustat firm in 2017 , this company remains a subsidiary of the same Compustat firm throughout our period. 
TABLE 2

\section{Descriptive Statistics}

Panel A: Descriptive Statistics for Voluntary Contribution Tests

\begin{tabular}{|c|c|c|c|c|c|c|c|c|c|}
\hline \multirow[b]{2}{*}{ Variable } & \multicolumn{2}{|c|}{$\begin{array}{c}\text { Full Sample } \\
(\mathrm{N}=\mathbf{3 , 8 8 5})\end{array}$} & \multicolumn{2}{|c|}{$\begin{array}{c}\text { Pre - TCJA }[\mathbf{A}] \\
\quad(\mathbf{N}=\mathbf{2 , 9 3 0 )}\end{array}$} & \multicolumn{2}{|c|}{$\begin{array}{l}\text { TCJA [B] } \\
(\mathbf{N}=955)\end{array}$} & \multicolumn{3}{|c|}{ Difference in Means } \\
\hline & Mean & SD & Mean & SD & Mean & SD & {$[\mathbf{B}]-[\mathbf{A}]$} & SE & \\
\hline Voluntary Contribution & 0.29 & 1.05 & 0.25 & 0.94 & 0.40 & 1.32 & 0.14 & 0.04 & $* * *$ \\
\hline $\begin{array}{l}\text { Voluntary Contribution } \\
\text { (unscaled), \$'m }\end{array}$ & 39.33 & 208.82 & 34.46 & 167.95 & 54.27 & 301.04 & 19.82 & 7.78 & $* *$ \\
\hline Mandatory Contribution & 0.14 & 0.41 & 0.14 & 0.42 & 0.13 & 0.37 & -0.007 & 0.015 & \\
\hline $\begin{array}{l}\text { Mandatory Contribution } \\
\text { (unscaled), \$'m }\end{array}$ & 9.67 & 47.67 & 9.28 & 43.77 & 10.86 & 58.03 & 1.57 & 1.78 & \\
\hline Total Contribution & 0.43 & 1.20 & 0.40 & 1.09 & 0.53 & 1.46 & 0.13 & 0.04 & $* * *$ \\
\hline $\begin{array}{l}\text { Total Contribution } \\
\text { (unscaled), \$’m }\end{array}$ & 50.07 & 247.93 & 45.06 & 205.00 & 65.42 & 347.73 & 20.36 & 9.23 & $* *$ \\
\hline TCJA & 0.25 & 0.43 & 0 & 0.00 & 1 & 0.00 & 1.00 & - & \\
\hline Taxpayer & 0.85 & 0.36 & 0.86 & 0.35 & 0.84 & 0.37 & -0.02 & 0.013 & \\
\hline FundRatio_5500 & 1.12 & 0.17 & 1.12 & 0.17 & 1.1182 & 0.169 & 0.00053 & 0.0063 & \\
\hline ActivePBO & 3.40 & 4.13 & 3.49 & 4.19 & 3.13 & 3.90 & -0.36 & 0.15 & $* *$ \\
\hline ActivePBO (unscaled), \$’m & 449.11 & 1155.16 & 462.19 & 1172.17 & 408.98 & 1100.96 & -53.21 & 43.04 & \\
\hline $\begin{array}{l}\text { Size (log of beginning firm } \\
\text { assets) }\end{array}$ & 8.50 & 1.74 & 8.51 & 1.74 & 8.46 & 1.75 & -0.05 & 0.06 & \\
\hline Beginning Firm Assets, \$'m & 21948.7 & 57386.2 & 22206.6 & 58035.2 & 21157.2 & 55369.9 & -1049.5 & 2138.5 & \\
\hline Lev & 0.33 & 0.23 & 0.32 & 0.23 & 0.35 & 0.23 & 0.03 & 0.009 & $* * *$ \\
\hline ROA & 0.06 & 0.08 & 0.061 & 0.08 & 0.062 & 0.07 & 0.00084 & 0.0029 & \\
\hline PPE & 0.33 & 0.27 & 0.33 & 0.27 & 0.32 & 0.26 & -0.02 & 0.01 & $*$ \\
\hline Sales Growth & 0.02 & 0.14 & 0.01 & 0.14 & 0.05 & 0.12 & 0.04 & 0.005 & $* * *$ \\
\hline
\end{tabular}


Panel B: Descriptive Statistics for Asset Allocation Tests

\begin{tabular}{|c|c|c|c|c|c|c|c|c|c|}
\hline \multirow[b]{3}{*}{ Variable } & & & \multicolumn{2}{|c|}{ Sample for Eq. (2) } & & & & \multicolumn{2}{|c|}{ Sample for Eq. (3) } \\
\hline & \multicolumn{2}{|c|}{$\begin{array}{c}\text { Pre-TCJA [A] } \\
\quad(\mathbf{N}=\mathbf{1 4 0 2})\end{array}$} & \multicolumn{2}{|c|}{$\begin{array}{c}\text { Post-TCJA [B] } \\
(\mathrm{N}=417)\end{array}$} & \multicolumn{3}{|c|}{ Difference in Means } & \multicolumn{2}{|c|}{$\begin{array}{c}\text { Full Period } \\
(\mathrm{N}=1819)\end{array}$} \\
\hline & Mean & SD & Mean & SD & {$[\mathbf{B}]-[\mathrm{A}]$} & SE & & Mean & SD \\
\hline$\Delta(\%$ Equity $)$ & -0.024 & 0.110 & -0.0795 & 0.148 & -0.055 & 0.0067 & $* * *$ & -0.037 & 0.122 \\
\hline $\begin{array}{l}\Delta(\% \text { Equity }+\% \text { RealEstate }) \\
\Delta(\% \text { Equity }+\% \text { RealEstate }\end{array}$ & -0.022 & 0.112 & -0.0807 & 0.150 & -0.058 & 0.0068 & $* * *$ & -0.036 & 0.124 \\
\hline$+\%$ Other) & -0.016 & 0.108 & -0.0789 & 0.170 & -0.063 & 0.007 & $* * *$ & -0.030 & 0.128 \\
\hline$\Delta(\%$ FixedIncome $)$ & 0.015 & 0.106 & 0.0813 & 0.165 & 0.066 & 0.0068 & $* * *$ & 0.030 & 0.125 \\
\hline Post_TCJA & 0 & 0 & 1 & 0 & 1 & - & & 0.23 & 0.42 \\
\hline$\Delta$ FundRatio & 0.025 & 0.10 & 0.037 & 0.07 & 0.012 & 0.005 & $* *$ & 0.028 & 0.10 \\
\hline$\Delta$ FundRatio_TCJA & - & - & 0.037 & 0.07 & - & - & & - & - \\
\hline$\Delta$ FundRatio_TCJA_VC & - & - & 0.16 & 0.34 & - & - & & - & - \\
\hline FundRatio & 0.80 & 0.14 & 0.83 & 0.15 & 0.03 & 0.008 & $* * *$ & 0.81 & 0.14 \\
\hline FundRatio^2 & 0.66 & 0.22 & 0.71 & 0.24 & 0.05 & 0.013 & $* * *$ & 0.67 & 0.23 \\
\hline ARR & 0.07 & 0.060 & -0.02 & 0.06 & -0.09 & 0.003 & $* * *$ & 0.05 & 0.07 \\
\hline Lag_ARR & 0.08 & 0.065 & 0.12 & 0.05 & 0.04 & 0.003 & $* * *$ & 0.09 & 0.06 \\
\hline DiscountRate & 4.23 & 0.48 & 3.99 & 0.52 & -0.24 & 0.027 & $* * *$ & 4.18 & 0.50 \\
\hline ROCI & 0.030 & 0.02 & 0.027 & 0.02 & -0.004 & 0.001 & $* * *$ & 0.03 & 0.02 \\
\hline $\begin{array}{l}\text { Lag2 (\%Equity) } \\
\text { Lag2 (\%Equity }\end{array}$ & 0.517 & 0.156 & 0.464 & 0.182 & -0.053 & 0.009 & $* * *$ & 0.50 & 0.164 \\
\hline $\begin{array}{l}+\% \text { RealEstate }) \\
\text { Lag2 (\%Equity }\end{array}$ & 0.534 & 0.159 & 0.483 & 0.186 & -0.051 & 0.0092 & $* * *$ & 0.52 & 0.167 \\
\hline$+\%$ RealEstate $+\%$ Others) & 0.596 & 0.152 & 0.570 & 0.180 & -0.025 & 0.0089 & $* * *$ & 0.59 & 0.159 \\
\hline Lag2 (\%FixedIncome) & 0.404 & 0.152 & 0.428 & 0.179 & 0.023 & 0.0088 & $* * *$ & 0.41 & 0.159 \\
\hline Horizon & 1.42 & 1.65 & 1.22 & 1.77 & -0.20 & 0.094 & $* *$ & 1.37 & 1.68 \\
\hline TaxBill & 0.013 & 0.02 & 0.007 & 0.01 & -0.007 & 0.001 & $* * *$ & 0.01 & 0.02 \\
\hline Size & 8.63 & 1.71 & 8.70 & 1.70 & 0.06 & 0.095 & & 8.65 & 1.71 \\
\hline Lev & 0.31 & 0.20 & 0.35 & 0.22 & 0.04 & 0.012 & $* * *$ & 0.32 & 0.21 \\
\hline Dividend & 0.0205 & 0.02 & 0.0211 & 0.02 & 0.0005 & 0.001 & & 0.02 & 0.02 \\
\hline SDCF & 0.475 & 1.83 & 0.472 & 1.64 & -0.003 & 0.0996 & & 0.47 & 1.79 \\
\hline MarketReturn & 0.08 & 0.09 & -0.07 & 0.06 & -0.16 & 0.005 & $* * *$ & 0.05 & 0.11 \\
\hline
\end{tabular}

Note:

$*, * *, * * *$ Denote statistical significance at the 10 percent, 5 percent, and 1 percent levels, respectively (two-tailed tests).

Panel A provides descriptive statistics for voluntary contribution tests. The sample is further partitioned by pre-TCJA and TCJA regime. Panel B provides descriptive statistics for asset allocation tests. The sample is further partitioned by pre-TCJA and postTCJA regime. Pre-TCJA observations have fiscal years ending before March $31^{\text {st }}, 2017$; TCJA observations have fiscal years ending on March $31^{\text {st }}, 2017$ to November 30 ${ }^{\text {th }}, 2018$; and Post-TCJA observations have fiscal years ending on December $31^{\text {st }}$, 2018 to November 30 $0^{\text {th }}, 2019$ (as shown in Figure 1). "SD" denotes standard deviation; "SE" denotes standard errors. All variables are defined in Appendix B. 
TABLE 3:

The Effect of the TCJA on Pension Contributions

\section{Panel A}

\begin{tabular}{|c|c|c|c|c|c|c|}
\hline \multirow[t]{2}{*}{ VARIABLES } & & JNTARY C & JTRIBUTI & & \multicolumn{2}{|c|}{$\begin{array}{c}\text { MANDATORY } \\
\text { CONTRIBUTIONS }\end{array}$} \\
\hline & (1) & (2) & (3) & (4) & (5) & $(6)$ \\
\hline TCJA & $\begin{array}{l}0.175^{* * *} \\
(0.0490)\end{array}$ & $\begin{array}{l}-0.110 \\
(0.0808)\end{array}$ & $\begin{array}{l}0.0765 \\
(0.102)\end{array}$ & $\begin{array}{l}-0.230 * \\
(0.117)\end{array}$ & $\begin{array}{c}0.000347 \\
(0.0442)\end{array}$ & $\begin{array}{l}-0.00569 \\
(0.0452)\end{array}$ \\
\hline Taxpayer & & $\begin{array}{l}0.162^{* *} \\
(0.0678)\end{array}$ & & $\begin{array}{l}0.165 * * \\
(0.0686)\end{array}$ & & $\begin{array}{c}0.0538^{* * * *} \\
(0.0189)\end{array}$ \\
\hline Taxpayer*TCJA & & $\begin{array}{l}0.348 * * * \\
(0.0843)\end{array}$ & & $\begin{array}{r}0.355 * * * \\
(0.0853)\end{array}$ & & $\begin{array}{l}0.00631 \\
(0.0251)\end{array}$ \\
\hline FundRatio_5500 & $\begin{array}{c}-1.490 * * * \\
(0.292)\end{array}$ & $\begin{array}{c}-1.477^{* * * *} \\
(0.280)\end{array}$ & $\begin{array}{c}-1.963 * * * \\
(0.371)\end{array}$ & $\begin{array}{c}-1.962^{* * * *} \\
(0.359)\end{array}$ & $\begin{array}{c}-0.824 * * * \\
(0.109)\end{array}$ & $\begin{array}{c}-0.814 * * * \\
(0.106)\end{array}$ \\
\hline ActivePBO & $\begin{array}{l}0.110^{* *} \\
(0.0454)\end{array}$ & $\begin{array}{l}0.106^{* *} \\
(0.0450)\end{array}$ & $\begin{array}{l}0.111^{* *} \\
(0.0455)\end{array}$ & $\begin{array}{l}0.108 * * \\
(0.0451)\end{array}$ & $\begin{array}{c}0.0481^{* * * *} \\
(0.0120)\end{array}$ & $\begin{array}{c}0.0474^{* * * *} \\
(0.0120)\end{array}$ \\
\hline Size & $\begin{array}{l}-0.352 \\
(0.384)\end{array}$ & $\begin{array}{l}-0.375 \\
(0.383)\end{array}$ & $\begin{array}{l}-0.380 \\
(0.389)\end{array}$ & $\begin{array}{l}-0.405 \\
(0.388)\end{array}$ & $\begin{array}{l}-0.00820 \\
(0.0426)\end{array}$ & $\begin{array}{l}-0.0111 \\
(0.0430)\end{array}$ \\
\hline Lag_Lev & $\begin{array}{c}0.366 \\
(0.320)\end{array}$ & $\begin{array}{c}0.392 \\
(0.323)\end{array}$ & $\begin{array}{c}0.339 \\
(0.319)\end{array}$ & $\begin{array}{c}0.364 \\
(0.322)\end{array}$ & $\begin{array}{l}0.0451 \\
(0.0595)\end{array}$ & $\begin{array}{c}0.0491 \\
(0.0598)\end{array}$ \\
\hline ROA & $\begin{array}{c}0.524 \\
(0.677)\end{array}$ & $\begin{array}{c}0.284 \\
(0.696)\end{array}$ & $\begin{array}{c}0.658 \\
(0.668)\end{array}$ & $\begin{array}{c}0.420 \\
(0.688)\end{array}$ & $\begin{array}{l}-0.180 \\
(0.138)\end{array}$ & $\begin{array}{l}-0.240^{*} \\
(0.145)\end{array}$ \\
\hline PPE & $\begin{array}{l}-1.089 \\
(0.966)\end{array}$ & $\begin{array}{l}-1.110 \\
(0.954)\end{array}$ & $\begin{array}{l}-1.152 \\
(0.975)\end{array}$ & $\begin{array}{l}-1.178 \\
(0.963)\end{array}$ & $\begin{array}{c}0.0158 \\
(0.0711)\end{array}$ & $\begin{array}{c}0.0144 \\
(0.0715)\end{array}$ \\
\hline SalesGrowth & $\begin{array}{c}0.151 \\
(0.178)\end{array}$ & $\begin{array}{c}0.150 \\
(0.170)\end{array}$ & $\begin{array}{c}0.236 \\
(0.174)\end{array}$ & $\begin{array}{c}0.238 \\
(0.167)\end{array}$ & $\begin{array}{c}0.0152 \\
(0.0340)\end{array}$ & $\begin{array}{c}0.0128 \\
(0.0338)\end{array}$ \\
\hline Constant & $\begin{array}{c}4.732 \\
(3.460)\end{array}$ & $\begin{array}{c}4.802 \\
(3.403)\end{array}$ & $\begin{array}{c}5.539 \\
(3.543)\end{array}$ & $\begin{array}{c}5.639 \\
(3.484)\end{array}$ & $\begin{array}{c}0.955^{* *} \\
(0.398)\end{array}$ & $\begin{array}{c}0.928^{* *} \\
(0.402)\end{array}$ \\
\hline Observations & 3,885 & 3,885 & 3,885 & 3,885 & 3,885 & 3,885 \\
\hline R-squared & $28.0 \%$ & $28.8 \%$ & $28.6 \%$ & $29.5 \%$ & $72.9 \%$ & $73.1 \%$ \\
\hline Firm Fixed Effects & Yes & Yes & Yes & Yes & Yes & Yes \\
\hline Year Fixed Effects & No & No & Yes & Yes & Yes & Yes \\
\hline Clustered SE by Firm & Yes & Yes & Yes & Yes & Yes & Yes \\
\hline
\end{tabular}

Note:

$* * *, * *, *$ denote significance at the $1 \%, 5 \%$, and $10 \%$ level, respectively, using two-tailed clustered standard errors at the firm level.

In panel A, the dependent variable Voluntary Contributions is voluntary contributions aggregated at firm-level and scaled by lagged assets. In panel B, the dependent variable Mandatory Contributions is mandatory contributions made after the carryover and prefunding balance elected for use to offset funding requirements (aggregated at firm level) and scaled by lagged assets.

$T C J A$ is an indicator variable equal to 1 in fiscal years ending on March $31^{\text {st }}, 2017$ to November $30^{\text {th }}$, 2018, and equal to 0 in fiscal years ending before March $31^{\text {st }}$, 2017. Taxpayer is an indicator variable equal to $1(0)$ when federal tax expense plus total contributions reported on Form 5500 multiplied by the highest statutory tax rate (35\%) is greater (equal to or lesser) than zero. Taxpayer*TCJA is an interactive term. All other variables are defined in Appendix B. 
Table 4

\section{Drivers of Voluntary Contributions in the TCJA Window}

Panel A - Plan-level Characteristics

\begin{tabular}{|c|c|c|c|c|c|}
\hline & \multicolumn{2}{|c|}{ Pension Funding Status } & \multirow{2}{*}{$\begin{array}{c}\text { Uncertainty } \\
\text { in Benefit } \\
\text { Payouts } \\
(3) \\
\text { ActivePBO }\end{array}$} & \multicolumn{2}{|c|}{ PBGC Premium Costs } \\
\hline & Underfund_pbo & Underfund_assets & & $\begin{array}{c}\text { (4) } \\
\text { Number of } \\
\text { Participants }\end{array}$ & $\begin{array}{c}\text { (5) } \\
\text { PBGC } \\
\text { Flat } \\
\text { Premiums }\end{array}$ \\
\hline TCJA & $\begin{array}{c}-0.00883 \\
(0.111)\end{array}$ & $\begin{array}{l}0.0351 \\
(0.105)\end{array}$ & $\begin{array}{l}-0.0395 \\
(0.102)\end{array}$ & $\begin{array}{l}0.0135 \\
(0.103)\end{array}$ & $\begin{array}{l}-0.0137 \\
(0.106)\end{array}$ \\
\hline High & Omitted & Omitted & Omitted & Omitted & Omitted \\
\hline TCJA*High & $\begin{array}{c}0.209 * * * \\
(0.0643)\end{array}$ & $\begin{array}{l}0.215 * * \\
(0.0912)\end{array}$ & $\begin{array}{c}0.238 * * * \\
(0.0659)\end{array}$ & $\begin{array}{c}0.138 * \\
(0.0714)\end{array}$ & $\begin{array}{c}0.203 * * * \\
(0.0677)\end{array}$ \\
\hline Taxpayer & $\begin{array}{c}0.278 * * * \\
(0.0714)\end{array}$ & $\begin{array}{c}0.265 * * * \\
(0.0679)\end{array}$ & $\begin{array}{c}0.285 * * * \\
(0.0745)\end{array}$ & $\begin{array}{c}0.263 * * * \\
(0.0678)\end{array}$ & $\begin{array}{c}0.268 * * * \\
(0.0681)\end{array}$ \\
\hline FundRatio_5500 & & $\begin{array}{c}-1.847 * * * \\
(0.354)\end{array}$ & $\begin{array}{c}-1.879 * * * \\
(0.365)\end{array}$ & $\begin{array}{c}-1.897 * * * \\
(0.357)\end{array}$ & $\begin{array}{c}-1.898 * * * \\
(0.357)\end{array}$ \\
\hline ActivePBO & $\begin{array}{l}0.108 * * \\
(0.0444)\end{array}$ & $\begin{array}{l}0.108 * * \\
(0.0447)\end{array}$ & & $\begin{array}{l}0.108 * * \\
(0.0448)\end{array}$ & $\begin{array}{l}0.112 * * \\
(0.0447)\end{array}$ \\
\hline Size & $\begin{array}{l}-0.438 \\
(0.390)\end{array}$ & $\begin{array}{l}-0.402 \\
(0.389)\end{array}$ & $\begin{array}{l}-0.639 \\
(0.511)\end{array}$ & $\begin{array}{l}-0.394 \\
(0.392)\end{array}$ & $\begin{array}{l}-0.376 \\
(0.393)\end{array}$ \\
\hline Lag_Lev & $\begin{array}{c}0.395 \\
(0.324)\end{array}$ & $\begin{array}{c}0.375 \\
(0.323)\end{array}$ & $\begin{array}{c}0.340 \\
(0.333)\end{array}$ & $\begin{array}{c}0.362 \\
(0.324)\end{array}$ & $\begin{array}{c}0.356 \\
(0.325)\end{array}$ \\
\hline ROA & $\begin{array}{l}0.0594 \\
(0.669)\end{array}$ & $\begin{array}{c}0.260 \\
(0.676)\end{array}$ & $\begin{array}{c}0.263 \\
(0.728)\end{array}$ & $\begin{array}{c}0.298 \\
(0.684)\end{array}$ & $\begin{array}{c}0.285 \\
(0.687)\end{array}$ \\
\hline PPE & $\begin{array}{l}-1.187 \\
(0.968)\end{array}$ & $\begin{array}{l}-1.118 \\
(0.961)\end{array}$ & $\begin{array}{l}-1.031 \\
(0.925)\end{array}$ & $\begin{array}{l}-1.124 \\
(0.964)\end{array}$ & $\begin{array}{l}-1.160 \\
(0.959)\end{array}$ \\
\hline SalesGrowth & $\begin{array}{c}0.220 \\
(0.176)\end{array}$ & $\begin{array}{c}0.199 \\
(0.169)\end{array}$ & $\begin{array}{c}0.163 \\
(0.168)\end{array}$ & $\begin{array}{c}0.196 \\
(0.169)\end{array}$ & $\begin{array}{c}0.199 \\
(0.170)\end{array}$ \\
\hline Constant & $\begin{array}{c}3.632 \\
(3.411)\end{array}$ & $\begin{array}{c}5.373 \\
(3.503)\end{array}$ & $\begin{array}{l}7.759 * \\
(4.649)\end{array}$ & $\begin{array}{c}5.372 \\
(3.532)\end{array}$ & $\begin{array}{c}5.215 \\
(3.540)\end{array}$ \\
\hline Observations & 3,859 & 3,859 & 3,859 & 3,859 & 3,854 \\
\hline R-squared & $20.0 \%$ & $21.4 \%$ & $20.2 \%$ & $21.3 \%$ & $21.5 \%$ \\
\hline Firm Fixed Effects & Yes & Yes & Yes & Yes & Yes \\
\hline Year Fixed Effects & Yes & Yes & Yes & Yes & Yes \\
\hline $\begin{array}{l}\text { Clustered SE by Firm } \\
\text { Mean of Partition }\end{array}$ & Yes & Yes & Yes & Yes & Yes \\
\hline $\begin{array}{l}\text { Variable } \\
\text { for High (Low) }\end{array}$ & -0.0012 & 0.0117 & 5.9460 & 37964.74 & 309.7186 \\
\hline Subsample & $(-0.2663)$ & $(0)$ & $(0.7555)$ & $(1795.29)$ & $(53.6237)$ \\
\hline $\begin{array}{l}\text { t-statistics for difference } \\
\text { between High and Low } \\
\text { subsamples }\end{array}$ & $33.79 * * *$ & $10.27 * * *$ & $22.81 * * *$ & $10.20 * * *$ & $7.40 * * *$ \\
\hline
\end{tabular}




\begin{tabular}{|c|c|c|c|}
\hline & \multicolumn{2}{|c|}{ Investment Opportunities } & \multirow{3}{*}{$\begin{array}{c}\text { Alternate uses of cash } \\
\text { (3) } \\
\text { Dividend }\end{array}$} \\
\hline & (1) & (2) & \\
\hline & MTB & Tobin's Q & \\
\hline \multirow[t]{2}{*}{ TCJA } & -0.0799 & -0.0731 & -0.0152 \\
\hline & $(0.108)$ & $(0.110)$ & $(0.112)$ \\
\hline High & Omitted & Omitted & Omitted \\
\hline \multirow[t]{2}{*}{ TCJA*High } & $0.301 * * *$ & $0.287 * * *$ & $0.185 * * *$ \\
\hline & $(0.0972)$ & $(0.101)$ & $(0.0665)$ \\
\hline \multirow[t]{2}{*}{ Taxpayer } & $0.282 * * *$ & $0.286^{* * *}$ & $0.258 * * *$ \\
\hline & $(0.0743)$ & $(0.0766)$ & $(0.0676)$ \\
\hline \multirow[t]{2}{*}{ FundRatio_5500 } & $-1.984 * * *$ & $-1.968 * * *$ & $-1.918 * * *$ \\
\hline & $(0.379)$ & $(0.395)$ & $(0.361)$ \\
\hline \multirow[t]{2}{*}{ ActivePBO } & $0.111 * *$ & $0.110 * *$ & $0.106^{* *}$ \\
\hline & $(0.0449)$ & $(0.0467)$ & $(0.0440)$ \\
\hline \multirow[t]{2}{*}{ Size } & -0.450 & -0.427 & -0.416 \\
\hline & $(0.404)$ & $(0.419)$ & $(0.395)$ \\
\hline \multirow[t]{2}{*}{ Lag_Lev } & 0.294 & 0.250 & 0.351 \\
\hline & $(0.311)$ & $(0.320)$ & $(0.323)$ \\
\hline \multirow[t]{2}{*}{ ROA } & 0.151 & 0.0703 & 0.314 \\
\hline & $(0.704)$ & $(0.736)$ & $(0.671)$ \\
\hline \multirow[t]{2}{*}{ PPE } & -1.232 & -1.247 & -1.167 \\
\hline & $(1.016)$ & $(1.041)$ & $(0.966)$ \\
\hline \multirow[t]{2}{*}{ SalesGrowth } & 0.216 & 0.232 & 0.185 \\
\hline & $(0.177)$ & $(0.191)$ & $(0.168)$ \\
\hline \multirow[t]{2}{*}{ Constant } & 5.960 & 5.747 & 5.607 \\
\hline & $(3.650)$ & $(3.766)$ & $(3.564)$ \\
\hline Observations & 3,569 & 3,402 & 3,844 \\
\hline R-squared & $21.4 \%$ & $21.3 \%$ & $21.4 \%$ \\
\hline Firm Fixed Effects & Yes & Yes & Yes \\
\hline Year Fixed Effects & Yes & Yes & Yes \\
\hline Clustered SE by Firm & Yes & Yes & Yes \\
\hline Mean of Partition Variable & 2.5330 & 2.4989 & 0.0381 \\
\hline for High (Low) Subsample & $(1.1837)$ & $(1.1390)$ & $(0.0039)$ \\
\hline $\begin{array}{l}\text { t-statistics for difference between } \\
\text { High and Low subsamples }\end{array}$ & $22.31 * * *$ & $22.10 * * *$ & $14.16^{* * *}$ \\
\hline
\end{tabular}

Note:

$* * *, * *, *$ denote significance at the $1 \%, 5 \%$, and $10 \%$ level, respectively, using two-tailed clustered standard errors at the firm level. We partition the sample on variables that capture the incentives to voluntarily contribute to DB plans. In Panel A, the sample is partitioned by plan characteristics, using a median split of underfunded obligations relative to total pension obligations (Underfund_pbo), underfunded obligations relative to firm size (Underfund_assets), proportion of the obligation owed to active participants, total number of participants, and PBGC flat premiums respectively in Columns (1)-(5). In Panel B, the sample is partitioned by firm-level characteristics, using a median split of market to book (MTB), Tobin's Q (TobinQ), and dividends paid (Dividend), in Columns (1)-(3). We estimate Equation (1) and include an indicator variable High equal to 1(0) if a firm's value of partitioning variable is above (below) the median and an interactive term between TCJA and High. Voluntary Contributions is the dependent variable, defined as voluntary contributions aggregated at firm-level and scaled by lagged assets. TCJA is an indicator variable equal to 1 in fiscal years ending between March $31^{\text {st }}, 2017$ and November $30^{\text {th }}, 2018$, and equal to 0 in fiscal years ending before March $31^{\text {st }}, 2017$. The variable of interest, TCJA*High, is an interactive term. All other variables are defined in Appendix B. 
Table 5

TCJA-Triggered Funding Changes and Shifts in Asset Allocation

Panel A: Change in Funding Ratio between Pre-TCJA and Post-TCJA Period

\begin{tabular}{|c|c|c|c|c|}
\hline & (1) & (2) & (3) & (4) \\
\hline & & $\Delta \% R I S K Y$ & & $\triangle \% S A F E$ \\
\hline & $\Delta \%$ Equity & $\begin{array}{l}\Delta \text { (\%Equity }+ \\
\% \text { RealEstate }) \\
\end{array}$ & $\begin{array}{c}\Delta \text { (\%Equity }+ \\
\% \text { RealEstate+ } \\
\% \text { Other })\end{array}$ & $\Delta \%$ FixedIncome \\
\hline$\Delta$ FundRatio_TCJA & $\begin{array}{c}-0.342 * * \\
(0.138)\end{array}$ & $\begin{array}{c}-0.353 * * \\
(0.141)\end{array}$ & $\begin{array}{c}-0.402 * * \\
(0.166)\end{array}$ & $\begin{array}{c}0.405 * * \\
(0.165)\end{array}$ \\
\hline FundRatio & $\begin{array}{l}-0.310 \\
(0.460)\end{array}$ & $\begin{array}{l}-0.266 \\
(0.458)\end{array}$ & $\begin{array}{l}-0.271 \\
(0.500)\end{array}$ & $\begin{array}{c}0.318 \\
(0.494)\end{array}$ \\
\hline FundRatio^2 & $\begin{array}{c}0.133 \\
(0.285)\end{array}$ & $\begin{array}{c}0.107 \\
(0.284)\end{array}$ & $\begin{array}{c}0.147 \\
(0.312)\end{array}$ & $\begin{array}{l}-0.179 \\
(0.307)\end{array}$ \\
\hline ARR & $\begin{array}{c}-1.701 * * * \\
(0.341)\end{array}$ & $\begin{array}{c}-1.713 * * * \\
(0.345)\end{array}$ & $\begin{array}{c}-2.042 * * * \\
(0.388)\end{array}$ & $\begin{array}{l}2.082 * * * \\
(0.385)\end{array}$ \\
\hline Lag_ARR & $\begin{array}{l}-0.223 \\
(0.307)\end{array}$ & $\begin{array}{l}-0.275 \\
(0.314)\end{array}$ & $\begin{array}{c}-0.304 \\
(0.451)\end{array}$ & $\begin{array}{c}0.492 \\
(0.415)\end{array}$ \\
\hline DiscountRate & $\begin{array}{c}0.0186 \\
(0.0150)\end{array}$ & $\begin{array}{c}0.0156 \\
(0.0147)\end{array}$ & $\begin{array}{l}-0.0118 \\
(0.0183)\end{array}$ & $\begin{array}{l}0.00921 \\
(0.0183)\end{array}$ \\
\hline ROCI & $\begin{array}{l}-0.105 \\
(0.484)\end{array}$ & $\begin{array}{c}0.00818 \\
(0.492)\end{array}$ & $\begin{array}{c}0.676 \\
(0.589)\end{array}$ & $\begin{array}{l}-0.657 \\
(0.586)\end{array}$ \\
\hline Lag2 (\%Equity) & $\begin{array}{c}-0.241 * * * \\
(0.0431)\end{array}$ & & & \\
\hline $\begin{array}{l}\text { Lag2 (\%Equity } \\
+\% \text { RealEstate) }\end{array}$ & & $\begin{array}{c}-0.223 * * * \\
(0.0416)\end{array}$ & & \\
\hline $\begin{array}{l}\text { Lag2 (\%Equity } \\
+\% \text { RealEstate+\%Other) }\end{array}$ & & & $\begin{array}{c}-0.175 * * * \\
(0.0651)\end{array}$ & \\
\hline Lag2 (\%FixedIncome) & & & & $\begin{array}{c}-0.136 * * * \\
(0.0514)\end{array}$ \\
\hline Horizon & $\begin{array}{c}0.00117 \\
(0.00277)\end{array}$ & $\begin{array}{l}0.000867 \\
(0.00277)\end{array}$ & $\begin{array}{l}-0.000984 \\
(0.00306)\end{array}$ & $\begin{array}{l}0.000960 \\
(0.00310)\end{array}$ \\
\hline TaxBill & $\begin{array}{c}1.005 \\
(0.688)\end{array}$ & $\begin{array}{c}1.058 \\
(0.710)\end{array}$ & $\begin{array}{l}1.799 * * \\
(0.818)\end{array}$ & $\begin{array}{c}-1.737 * * \\
(0.820)\end{array}$ \\
\hline Size & $\begin{array}{c}0.00228 \\
(0.00445)\end{array}$ & $\begin{array}{c}0.00309 \\
(0.00450)\end{array}$ & $\begin{array}{c}0.00708 \\
(0.00557)\end{array}$ & $\begin{array}{l}-0.00611 \\
(0.00548)\end{array}$ \\
\hline Lev & $\begin{array}{c}0.0317 \\
(0.0263)\end{array}$ & $\begin{array}{c}0.0353 \\
(0.0264)\end{array}$ & $\begin{array}{l}0.0511^{*} \\
(0.0288)\end{array}$ & $\begin{array}{c}-0.0574 * * \\
(0.0281)\end{array}$ \\
\hline Dividend & $\begin{array}{c}-0.314 \\
(0.329)\end{array}$ & $\begin{array}{l}-0.349 \\
(0.334)\end{array}$ & $\begin{array}{l}-0.437 \\
(0.368)\end{array}$ & $\begin{array}{c}0.404 \\
(0.367)\end{array}$ \\
\hline SDCF & $\begin{array}{c}0.00775 * * \\
(0.00374)\end{array}$ & $\begin{array}{c}0.00908 * * \\
(0.00407)\end{array}$ & $\begin{array}{c}0.00868 * * \\
(0.00370)\end{array}$ & $\begin{array}{c}-0.00941^{* *} \\
(0.00366)\end{array}$ \\
\hline MarketReturn & $\begin{array}{c}1.722 * * * \\
(0.329)\end{array}$ & $\begin{array}{c}1.657 * * * \\
(0.325)\end{array}$ & $\begin{array}{c}1.706^{* * *} * \\
(0.363)\end{array}$ & $\begin{array}{c}-1.654 * * * \\
(0.363)\end{array}$ \\
\hline Constant & $\begin{array}{c}0.223 \\
(0.191)\end{array}$ & $\begin{array}{c}0.202 \\
(0.189)\end{array}$ & $\begin{array}{c}0.225 \\
(0.218)\end{array}$ & $\begin{array}{c}-0.0940 \\
(0.213)\end{array}$ \\
\hline Observations & 417 & 417 & 417 & 417 \\
\hline R-squared & $25.8 \%$ & $25.0 \%$ & $20.8 \%$ & $20.8 \%$ \\
\hline Firm Fixed Effects & No & No & No & No \\
\hline Year Fixed Effects & No & No & No & No \\
\hline Robust SE & Yes & Yes & Yes & Yes \\
\hline
\end{tabular}


Panel B: Change in Funding Ratio Triggered by Voluntary Contribution in the TCJA Period

\begin{tabular}{|c|c|c|c|c|}
\hline & (1) & $(2)$ & (3) & (4) \\
\hline & $\Delta \%$ Equity & $\begin{array}{l}\Delta \text { (\%Equity }+ \\
\% \text { RealEstate })\end{array}$ & $\begin{array}{c}\Delta \text { (\%Equity }+ \\
\% \text { RealEstate+ } \\
\% \text { Other })\end{array}$ & $\Delta \%$ FixedIncome \\
\hline$\Delta$ FundRatio_TCJA_VC & $\begin{array}{c}-0.0925 * * * \\
(0.0295)\end{array}$ & $\begin{array}{c}-0.0941 * * * \\
(0.0301)\end{array}$ & $\begin{array}{c}-0.0814 * * \\
(0.0414)\end{array}$ & $\begin{array}{c}0.0839 * * \\
(0.0400)\end{array}$ \\
\hline FundRatio & $\begin{array}{l}-0.426 \\
(0.429)\end{array}$ & $\begin{array}{l}-0.381 \\
(0.429)\end{array}$ & $\begin{array}{l}-0.342 \\
(0.473)\end{array}$ & $\begin{array}{c}0.394 \\
(0.467)\end{array}$ \\
\hline FundRatio^2 & $\begin{array}{c}0.185 \\
(0.264)\end{array}$ & $\begin{array}{c}0.158 \\
(0.264)\end{array}$ & $\begin{array}{c}0.163 \\
(0.294)\end{array}$ & $\begin{array}{l}-0.198 \\
(0.289)\end{array}$ \\
\hline ARR & $\begin{array}{c}-1.675 * * * \\
(0.346)\end{array}$ & $\begin{array}{c}-1.686^{* * *} \\
(0.352)\end{array}$ & $\begin{array}{c}-2.041 * * * \\
(0.417)\end{array}$ & $\begin{array}{c}2.079 * * * \\
(0.412)\end{array}$ \\
\hline Lag_ARR & $\begin{array}{l}-0.498^{*} \\
(0.299)\end{array}$ & $\begin{array}{l}-0.549 * \\
(0.308)\end{array}$ & $\begin{array}{l}-0.584 \\
(0.441)\end{array}$ & $\begin{array}{l}0.777 * \\
(0.405)\end{array}$ \\
\hline DiscountRate & $\begin{array}{l}0.0303 * * \\
(0.0151)\end{array}$ & $\begin{array}{l}0.0276^{*} \\
(0.0149)\end{array}$ & $\begin{array}{l}-0.00117 \\
(0.0187)\end{array}$ & $\begin{array}{l}-0.00178 \\
(0.0186)\end{array}$ \\
\hline ROCI & $\begin{array}{l}-0.114 \\
(0.494)\end{array}$ & $\begin{array}{l}0.00225 \\
(0.501)\end{array}$ & $\begin{array}{c}0.690 \\
(0.615)\end{array}$ & $\begin{array}{l}-0.669 \\
(0.611)\end{array}$ \\
\hline Lag (\%Equity) & $\begin{array}{l}-0.253 * * * \\
(0.0418)\end{array}$ & & & \\
\hline Lag (\%Equity $+\%$ RealEstate $)$ & & $\begin{array}{l}-0.237 * * * \\
(0.0404)\end{array}$ & & \\
\hline $\begin{array}{l}\text { Lag (\%Equity } \\
+\% \text { RealEstate+\%Other) }\end{array}$ & & & $\begin{array}{c}-0.185 * * * \\
(0.0671)\end{array}$ & \\
\hline Lag (\%FixedIncome) & & & & $\begin{array}{c}-0.146^{* * *} \\
(0.0540)\end{array}$ \\
\hline Horizon & $\begin{array}{l}0.000262 \\
(0.00265)\end{array}$ & $\begin{array}{c}-0.0000684 \\
(0.00266)\end{array}$ & $\begin{array}{l}-0.00195 \\
(0.00314)\end{array}$ & $\begin{array}{c}0.00194 \\
(0.00319)\end{array}$ \\
\hline TaxBill & $\begin{array}{c}0.617 \\
(0.698)\end{array}$ & $\begin{array}{c}0.658 \\
(0.720)\end{array}$ & $\begin{array}{c}1.343 \\
(0.831)\end{array}$ & $\begin{array}{l}-1.278 \\
(0.834)\end{array}$ \\
\hline Size & $\begin{array}{l}-0.000508 \\
(0.00444)\end{array}$ & $\begin{array}{l}0.000256 \\
(0.00452)\end{array}$ & $\begin{array}{c}0.00487 \\
(0.00534)\end{array}$ & $\begin{array}{l}-0.00383 \\
(0.00526)\end{array}$ \\
\hline Lag_Lev & $\begin{array}{c}0.0279 \\
(0.0263)\end{array}$ & $\begin{array}{c}0.0316 \\
(0.0266)\end{array}$ & $\begin{array}{c}0.0495 \\
(0.0302)\end{array}$ & $\begin{array}{l}-0.0556 * \\
(0.0296)\end{array}$ \\
\hline Dividend & $\begin{array}{l}-0.297 \\
(0.335)\end{array}$ & $\begin{array}{l}-0.332 \\
(0.340)\end{array}$ & $\begin{array}{l}-0.397 \\
(0.376)\end{array}$ & $\begin{array}{c}0.365 \\
(0.375)\end{array}$ \\
\hline SDCF & $\begin{array}{l}0.00695^{*} \\
(0.00382)\end{array}$ & $\begin{array}{c}0.00824 * * \\
(0.00418)\end{array}$ & $\begin{array}{c}0.00744 * * \\
(0.00352)\end{array}$ & $\begin{array}{c}-0.00819 * * \\
(0.00348)\end{array}$ \\
\hline MarketReturn & $\begin{array}{c}1.521 * * * \\
(0.323)\end{array}$ & $\begin{array}{c}1.455^{* * * *} \\
(0.317)\end{array}$ & $\begin{array}{c}1.528 * * * \\
(0.375)\end{array}$ & $\begin{array}{c}-1.471 * * * \\
(0.373)\end{array}$ \\
\hline Constant & $0.290 *$ & 0.269 & 0.277 & -0.138 \\
\hline
\end{tabular}


Year Fixed Effects

No

No

No

Yes

Note:

$* * *, * *, *$ denote significance at the $1 \%, 5 \%$, and $10 \%$ level, respectively, using two-tailed clustered standard errors at the firm level. We estimate Equation (2) in Table 5. The variable of interest in Panel A is $\triangle F$ FundRatio_TCJA, calculated as the change in GAAP funding ratio between the post-TCJA period and two years prior. The variable of interest in Panel B is $\triangle$ FundRatio TCJA_VC, calculated as the change in GAAP funding ratio triggered by voluntary contributions made in the TCJA period, where voluntary contributions are compounded by discount rate assumption reported on the post-TCJA 10-Ks. In column (1), the dependent variable $\Delta \%$ Equity is change in percentage of pension assets invested in equity securities between the post-TCJA period and two years prior (i.e., before the start of the window of opportunity). In column (2), the dependent variable $\Delta$ $(\%$ Equity $+\%$ RealEstate $)$ is change in percentage of pension assets invested in equity securities and real estate between the postTCJA period and two years prior (i.e., before the start of the window of opportunity). In column (3), the dependent variable $\Delta$ $(\%$ Equity $+\%$ RealEstate $\%$ Other $)$ is change in percentage of pension assets invested in equity securities, real estate, and other assets between the post-TCJA period and two years prior (i.e., before the start of the window of opportunity). In column (4), the dependent variable $\Delta$ (\%FixedIncome) is change in percentage of pension assets invested in fixed income securities between the post-TCJA period and two years prior (i.e., before the start of the window of opportunity). All other variables are defined in Appendix B. 
Table 6

The Relation Between Pension Funding and Asset Allocation over Pre- and Post-TCJA periods

\begin{tabular}{|c|c|c|c|c|c|c|c|c|}
\hline \multirow[b]{3}{*}{ VARIABLES } & (1) & (2) & (3) & (4) & (5) & (6) & (7) & (8) \\
\hline & \multicolumn{6}{|c|}{$\Delta \%$ RISKY } & \multicolumn{2}{|c|}{$\triangle \% \mathrm{SAFE}$} \\
\hline & \multicolumn{2}{|c|}{$\Delta \%$ Equity } & \multicolumn{2}{|c|}{$\begin{array}{c}\Delta \text { (\% Equity } \\
+\% \text { RealEstate }) \\
\end{array}$} & \multicolumn{2}{|c|}{$\begin{aligned} & \Delta(\% \text { Equity } \\
+ & \% \text { RealEstate } \\
+ & \% \text { Other })\end{aligned}$} & $\Delta \%$ Fix & Income \\
\hline Post_TCJA & $\begin{array}{c}-0.0744 * * * \\
(0.0203)\end{array}$ & $\begin{array}{c}-0.0560 * * * \\
(0.0169)\end{array}$ & $\begin{array}{c}-0.0762 * * * \\
(0.0206)\end{array}$ & $\begin{array}{c}-0.0594 * * * \\
(0.0170)\end{array}$ & $\begin{array}{c}-0.0665 * * * \\
(0.0207)\end{array}$ & $\begin{array}{c}-0.0445 * * \\
(0.0172)\end{array}$ & $\begin{array}{c}0.0693 * * * \\
(0.0207)\end{array}$ & $\begin{array}{c}0.0487 * * * \\
(0.0169)\end{array}$ \\
\hline$\Delta$ FundRatio & $\begin{array}{l}-0.0300 \\
(0.0658)\end{array}$ & $\begin{array}{c}0.0829 \\
(0.0600)\end{array}$ & $\begin{array}{l}-0.0285 \\
(0.0669)\end{array}$ & $\begin{array}{c}0.0849 \\
(0.0606)\end{array}$ & $\begin{array}{l}-0.0271 \\
(0.0563)\end{array}$ & $\begin{array}{c}0.105^{*} \\
(0.0567)\end{array}$ & $\begin{array}{c}0.0222 \\
(0.0565)\end{array}$ & $\begin{array}{l}-0.114 * * \\
(0.0569)\end{array}$ \\
\hline Post_TCJA $* \Delta$ FundRatio & $\begin{array}{c}-0.405 * * \\
(0.166)\end{array}$ & $\begin{array}{c}-0.449 * * * \\
(0.156)\end{array}$ & $\begin{array}{c}-0.416 * * \\
(0.168)\end{array}$ & $\begin{array}{c}-0.460 * * * \\
(0.158)\end{array}$ & $\begin{array}{c}-0.454 * * \\
(0.179)\end{array}$ & $\begin{array}{c}-0.354 * * \\
(0.179)\end{array}$ & $\begin{array}{c}0.458 * * \\
(0.179)\end{array}$ & $\begin{array}{c}0.352 * * \\
(0.179)\end{array}$ \\
\hline FundRatio & $\begin{array}{l}-0.258 \\
(0.210)\end{array}$ & $\begin{array}{c}0.130 \\
(0.366)\end{array}$ & $\begin{array}{l}-0.198 \\
(0.211)\end{array}$ & $\begin{array}{c}0.107 \\
(0.375)\end{array}$ & $\begin{array}{l}-0.248 \\
(0.215)\end{array}$ & $\begin{array}{c}0.191 \\
(0.359)\end{array}$ & $\begin{array}{c}0.241 \\
(0.213)\end{array}$ & $\begin{array}{l}-0.196 \\
(0.357)\end{array}$ \\
\hline FundRatio^2 & $\begin{array}{c}0.124 \\
(0.137)\end{array}$ & $\begin{array}{l}-0.185 \\
(0.227)\end{array}$ & $\begin{array}{l}0.0870 \\
(0.137)\end{array}$ & $\begin{array}{l}-0.174 \\
(0.232)\end{array}$ & $\begin{array}{c}0.139 \\
(0.140)\end{array}$ & $\begin{array}{l}-0.284 \\
(0.225)\end{array}$ & $\begin{array}{l}-0.136 \\
(0.139)\end{array}$ & $\begin{array}{c}0.291 \\
(0.224)\end{array}$ \\
\hline ARR & $\begin{array}{c}0.110 \\
(0.0898)\end{array}$ & $\begin{array}{l}-0.0113 \\
(0.101)\end{array}$ & $\begin{array}{c}0.0960 \\
(0.0910)\end{array}$ & $\begin{array}{l}-0.0204 \\
(0.102)\end{array}$ & $\begin{array}{l}-0.00139 \\
(0.0911)\end{array}$ & $\begin{array}{l}-0.0317 \\
(0.0991)\end{array}$ & $\begin{array}{l}0.00283 \\
(0.0908)\end{array}$ & $\begin{array}{c}0.0335 \\
(0.0994)\end{array}$ \\
\hline Lag_ARR & $\begin{array}{c}0.261 * * * \\
(0.0855)\end{array}$ & $\begin{array}{c}0.0545 \\
(0.0791)\end{array}$ & $\begin{array}{c}0.243 * * * \\
(0.0860)\end{array}$ & $\begin{array}{c}0.0486 \\
(0.0789)\end{array}$ & $\begin{array}{c}0.172 * \\
(0.0895)\end{array}$ & $\begin{array}{l}-0.0200 \\
(0.0785)\end{array}$ & $\begin{array}{l}-0.150^{*} \\
(0.0867)\end{array}$ & $\begin{array}{c}0.0305 \\
(0.0783)\end{array}$ \\
\hline DiscountRate & $\begin{array}{l}0.0175 * * \\
(0.00795)\end{array}$ & $\begin{array}{c}0.0299 * * \\
(0.0126)\end{array}$ & $\begin{array}{l}0.0182 * * \\
(0.00797)\end{array}$ & $\begin{array}{c}0.0312 * * \\
(0.0130)\end{array}$ & $\begin{array}{c}0.0115 \\
(0.00861)\end{array}$ & $\begin{array}{c}0.0358 * * * \\
(0.0137)\end{array}$ & $\begin{array}{c}-0.0112 \\
(0.00855)\end{array}$ & $\begin{array}{c}-0.0358 * * * \\
(0.0136)\end{array}$ \\
\hline ROCI & $\begin{array}{l}-0.223 \\
(0.257)\end{array}$ & $\begin{array}{l}0.0628 \\
(0.595)\end{array}$ & $\begin{array}{l}-0.176 \\
(0.266)\end{array}$ & $\begin{array}{l}0.0155 \\
(0.606)\end{array}$ & $\begin{array}{c}0.129 \\
(0.278)\end{array}$ & $\begin{array}{l}0.0469 \\
(0.583)\end{array}$ & $\begin{array}{l}-0.122 \\
(0.276)\end{array}$ & $\begin{array}{c}-0.0696 \\
(0.581)\end{array}$ \\
\hline Lag2 (\%Equity) & $\begin{array}{c}-0.210 * * * \\
(0.0243)\end{array}$ & $\begin{array}{c}-0.905 * * * \\
(0.0413)\end{array}$ & & & & & & \\
\hline Lag 2(\%Equity + \%RealEstate) & & & $\begin{array}{c}-0.198 * * * \\
(0.0241)\end{array}$ & $\begin{array}{c}-0.902 * * * \\
(0.0407)\end{array}$ & & & & \\
\hline Lag2 (\%Equity $+\%$ RealEstate $+\%$ Other $)$ & & & & & $\begin{array}{c}-0.170 * * * \\
(0.0272)\end{array}$ & $\begin{array}{c}-0.903 * * * \\
(0.0551)\end{array}$ & & \\
\hline
\end{tabular}




\begin{tabular}{|c|c|c|c|c|c|c|c|c|}
\hline & & & & & & & $(0.0243)$ & $(0.0470)$ \\
\hline \multirow[t]{2}{*}{ Horizon } & $0.00503 * * *$ & -0.00198 & $0.00460 * *$ & -0.00230 & $0.00450 * *$ & -0.00139 & $-0.00450 * *$ & 0.00100 \\
\hline & $(0.00177)$ & $(0.00372)$ & $(0.00179)$ & $(0.00371)$ & $(0.00216)$ & $(0.00509)$ & $(0.00215)$ & $(0.00507)$ \\
\hline \multirow[t]{2}{*}{ TaxBill } & 0.102 & 0.0710 & 0.122 & 0.0970 & -0.0202 & 0.0754 & 0.0418 & 0.0300 \\
\hline & $(0.226)$ & $(0.304)$ & $(0.233)$ & $(0.293)$ & $(0.238)$ & $(0.317)$ & $(0.236)$ & $(0.309)$ \\
\hline \multirow[t]{2}{*}{ Size } & -0.00326 & 0.00899 & -0.00272 & 0.00608 & -0.00224 & 0.000170 & 0.00210 & 0.00137 \\
\hline & $(0.00222)$ & $(0.0123)$ & $(0.00223)$ & $(0.0126)$ & $(0.00233)$ & $(0.0137)$ & $(0.00232)$ & $(0.0135)$ \\
\hline \multirow[t]{2}{*}{ Lag_Lev } & 0.0169 & 0.0162 & 0.0180 & 0.0157 & 0.0147 & 0.0171 & -0.0143 & -0.0170 \\
\hline & $(0.0146)$ & $(0.0194)$ & $(0.0149)$ & $(0.0194)$ & $(0.0150)$ & $(0.0211)$ & $(0.0150)$ & $(0.0211)$ \\
\hline \multirow[t]{2}{*}{ Dividend } & -0.0108 & -0.272 & -0.0415 & -0.302 & -0.0114 & -0.487 & 0.00389 & 0.437 \\
\hline & $(0.175)$ & $(0.299)$ & $(0.176)$ & $(0.296)$ & $(0.185)$ & $(0.302)$ & $(0.184)$ & (0.299) \\
\hline \multirow[t]{2}{*}{ SDCF } & -0.0000939 & -0.00221 & 0.000339 & $-0.00454 * *$ & 0.0000658 & -0.00103 & -0.000115 & 0.00107 \\
\hline & $(0.00195)$ & $(0.00156)$ & $(0.00206)$ & $(0.00203)$ & $(0.00179)$ & $(0.00217)$ & $(0.00178)$ & $(0.00218)$ \\
\hline \multirow[t]{2}{*}{ MarketReturn } & $0.184 * * *$ & $0.0998^{*}$ & $0.173 * * *$ & $0.0903^{*}$ & $0.199 * * *$ & $0.0983^{* *}$ & $-0.200 * * *$ & $-0.103 * *$ \\
\hline & $(0.0567)$ & $(0.0511)$ & $(0.0575)$ & $(0.0515)$ & $(0.0581)$ & $(0.0476)$ & $(0.0580)$ & $(0.0475)$ \\
\hline \multirow[t]{2}{*}{ Trend } & $0.0161 * * *$ & 0.000206 & $0.0156 * * *$ & 0.000675 & $0.0123 * *$ & 0.00135 & $-0.0126 * *$ & -0.00250 \\
\hline & $(0.00550)$ & $(0.00500)$ & $(0.00556)$ & $(0.00503)$ & $(0.00579)$ & $(0.00498)$ & $(0.00581)$ & $(0.00491)$ \\
\hline \multirow[t]{2}{*}{ Constant } & 0.0723 & 0.243 & 0.0442 & 0.293 & 0.0876 & $0.396 * *$ & 0.0785 & $0.482 * * *$ \\
\hline & $(0.0794)$ & $(0.180)$ & $(0.0800)$ & $(0.193)$ & $(0.0870)$ & $(0.179)$ & $(0.0869)$ & $(0.176)$ \\
\hline Observations & 1,819 & 1,819 & 1,819 & 1,819 & 1,819 & 1,819 & 1,819 & 1,819 \\
\hline R-squared & $13.9 \%$ & $50.3 \%$ & $13.3 \%$ & $50.9 \%$ & $11.9 \%$ & $49.3 \%$ & $12.2 \%$ & $49.9 \%$ \\
\hline Firm Fixed Effects & No & Yes & No & Yes & No & Yes & No & Yes \\
\hline Year Fixed Effects & No & No & No & No & No & No & No & No \\
\hline Clustered SE by Firm & Yes & Yes & Yes & Yes & Yes & Yes & Yes & Yes \\
\hline
\end{tabular}

Note:

$* * *, * *, *$ denote significance at the $1 \%, 5 \%$, and $10 \%$ level, respectively, using two-tailed clustered standard errors at the firm level.

In column (1) - (2), the dependent variable $\Delta \%$ Equity is two-year change in percentage of pension assets invested in equity securities. In column (3) - (4), the dependent variable $\Delta$ $(\%$ Equity $+\%$ RealEstate $)$ is two-year change in percentage of pension assets invested in equity securities and real estate. In column (5) - (6), the dependent variable $\Delta$ (\%Equity + \%RealEstate+\%Other) is two-year change in percentage of pension assets invested in equity securities, real estate, and other assets. In column (7) - (8), the dependent variable $\Delta(\%$ FixedIncome $)$ is two-year change in percentage of pension assets invested in fixed income securities. Post-TCJA is an indicator variable equal to 1 in fiscal years ending between December 31 $1^{\text {st }}, 2018$ and November $30^{\text {th }}, 2019$, and equal to 0 in fiscal years ending before March $31^{\text {st }}, 2017 . \Delta F u n d R a t i o$ is two-year change in FundRatio.

The variable of interest, Post-TCJA* $\Delta$ FundRatio, is an interactive term. All other variables are defined in Appendix B 
TABLE 7

TCJA-Triggered Funding Changes and PRT Transactions: Univariate Analyses

Difference in Means by Subgroup

\begin{tabular}{|c|c|c|c|c|c|c|c|c|c|c|}
\hline \multirow[b]{2}{*}{ Variable } & \multicolumn{3}{|c|}{ Before TCJA was Signed [A] } & \multicolumn{3}{|c|}{ After TCJA was Signed [B] } & \multicolumn{4}{|c|}{ Difference in Means } \\
\hline & $\mathbf{N}$ & Mean & SD & $\mathbf{N}$ & Mean & SD & {$[\mathbf{B}]-[\mathrm{A}]$} & SE & $\mathbf{t}$ & \\
\hline \multicolumn{11}{|c|}{ Sponsors that are less responsive to the TCJA (1) } \\
\hline Number of PRT completed & 1991 & 0.020 & 0.156 & 721 & 0.026 & 0.184 & 0.007 & 0.007 & 0.950 & \\
\hline Assets Transferred (unscaled) \$'m & 1977 & 5.721 & 86.476 & 720 & 11.678 & 225.503 & 5.957 & 6.008 & 0.992 & \\
\hline Assets Transferred scaled by PBO & 1968 & 0.002 & 0.021 & 720 & 0.003 & 0.028 & 0.001 & 0.001 & 1.388 & \\
\hline $\begin{array}{l}\text { Assets Transferred (unscaled) for } \\
\text { observations involved in PRT }\end{array}$ & 20 & 565.524 & 666.689 & 15 & 560.533 & 1510.615 & -4.990 & 377.891 & -0.013 & \\
\hline $\begin{array}{l}\text { Assets Transferred (scaled by PBO) } \\
\text { for observations involved in PRT }\end{array}$ & 20 & 0.152 & 0.143 & 15 & 0.140 & 0.136 & -0.012 & 0.048 & -0.247 & \\
\hline \multicolumn{11}{|c|}{ Sponsors that are more responsive to the TCJA (2) } \\
\hline Number of PRT completed & 2013 & 0.024 & 0.168 & 734 & 0.054 & 0.290 & 0.031 & 0.009 & 3.419 & $* * *$ \\
\hline Assets Transferred (unscaled) \$'m & 2001 & 31.756 & 771.474 & 731 & 34.941 & 285.218 & 3.185 & 29.241 & 0.109 & \\
\hline Assets Transferred scaled by PBO & 1998 & 0.002 & 0.020 & 731 & 0.010 & 0.076 & 0.008 & 0.002 & 4.562 & $* * *$ \\
\hline $\begin{array}{l}\text { Assets Transferred (unscaled) for } \\
\text { observations involved in PRT } \\
\text { Assets Transferred (scaled by PBO) }\end{array}$ & 31 & 2049.793 & 5950.104 & 27 & 946.004 & 1178.570 & -1103.789 & 1165.744 & -0.947 & \\
\hline for observations involved in PRT & 31 & 0.122 & 0.113 & 27 & 0.281 & 0.288 & 0.159 & 0.056 & 2.834 & $* * *$ \\
\hline
\end{tabular}

\section{Difference-in-Differences}

\begin{tabular}{lrrrll} 
& \multicolumn{3}{c}{ (2) vs. (1) } & & \multicolumn{1}{c}{ (1) } \\
\hline Variable & \multicolumn{1}{c}{ DiD } & \multicolumn{1}{c}{ SE } & \multicolumn{1}{c}{ t } & \\
\hline Number of PRT completed & 0.028 & 0.013 & 2.202 & $* *$ \\
Assets Transferred (unscaled) \$'m & 23.264 & 13.511 & 1.722 & $*$ \\
Assets Transferred scaled by PBO & 0.007 & 0.003 & 2.480 & $* *$
\end{tabular}




\section{Difference-in-Differences (Continued)}

\begin{tabular}{lccc} 
& \multicolumn{3}{c}{ (2) vs. (1) } \\
\cline { 1 - 2 } Variable & DiD & SE & t \\
\hline $\begin{array}{l}\text { Assets Transferred (unscaled) for } \\
\text { observations involved in PRT }\end{array}$ & 385.470 & 420.068 & 0.918 \\
$\begin{array}{l}\text { Assets Transferred (scaled by PBO) } \\
\text { observations involved in PRT }\end{array}$ & 0.141 & 0.079 & $1.781 *$ \\
\hline
\end{tabular}

Note:

$* * *, * *, *$ denote significance at the $1 \%, 5 \%$, and $10 \%$ level, respectively (two-tailed tests).

The TCJA was signed on December $22^{\text {nd }}, 2017$. We partition the sample by responsiveness of sponsors to the TCJA. Responsiveness of sponsors to the TCJA is captured by change in funding ratio between the post-TCJA period and the signing of TCJA ( $\triangle$ FundRatio_TCJA). Sponsors that are less responsive to the TCJA are those ranking below the median value of $\triangle$ FundRatio while sponsors that are more responsive to the TCJA are those ranking above the median value of $\triangle F$ FundRatio. "Number of PRT completed" describes an indicator variable set to one if a PRT transaction was completed, and to zero if not. "Assets transferred (unscaled) \$' $m$ " describes the value of pension assets transferred in the PRT transaction, with the value set to zero for firm-years with no PRT. "Assets transferred scaled by PBO" describes the value of pension assets transferred in the PRT transaction / beginning-of-year PBO, with the value set to zero for firm-years with no PRT. 


\section{ONLINE APPENDIX}

\section{TABLE OA1}

\section{The Effect of the TCJA on Pension Contributions - No Fixed Effects}

\begin{tabular}{|c|c|c|c|c|c|c|}
\hline \multirow[t]{2}{*}{ VARIABLES } & \multicolumn{3}{|c|}{ VOLUNTARY CONTRIBUTIONS } & \multicolumn{3}{|c|}{ MANDATORY CONTRIBUTIONS } \\
\hline & (1) & (2) & (3) & (4) & (5) & (6) \\
\hline TCJA & $\begin{array}{c}\mathbf{0 . 1 5 3} * * * \\
(0.0533)\end{array}$ & $\begin{array}{c}0.156^{* * * *} \\
(0.0533)\end{array}$ & $\begin{array}{c}-0.0747 * * \\
(0.0329)\end{array}$ & $\begin{array}{l}0.00209 \\
(0.0103)\end{array}$ & $\begin{array}{l}0.00414 \\
(0.0102)\end{array}$ & $\begin{array}{c}0.0583 \\
(0.0416)\end{array}$ \\
\hline Taxpayer & & $\begin{array}{c}0.125^{* * *} \\
(0.0273)\end{array}$ & $\begin{array}{c}0.0514 \\
(0.0314)\end{array}$ & & $\begin{array}{c}0.0779^{* * * *} \\
(0.0189)\end{array}$ & $\begin{array}{c}0.0951^{* * * *} \\
(0.0268)\end{array}$ \\
\hline Taxpayer*TCJA & & & $\begin{array}{c}0.274 * * * \\
(0.0646)\end{array}$ & & & $\begin{array}{c}-0.0642 \\
(0.0504)\end{array}$ \\
\hline FundRatio_5500 & $\begin{array}{c}-0.270^{* * *} \\
(0.106)\end{array}$ & $\begin{array}{c}-0.254^{* *} \\
(0.108)\end{array}$ & $\begin{array}{c}-0.257^{* *} \\
(0.108)\end{array}$ & $\begin{array}{c}-0.717 * * * \\
(0.0806)\end{array}$ & $\begin{array}{c}-0.707 * * * \\
(0.0792)\end{array}$ & $\begin{array}{c}-0.706 * * * \\
(0.0789)\end{array}$ \\
\hline ActivePBO & $\begin{array}{c}0.0716^{* * * *} \\
(0.0138)\end{array}$ & $\begin{array}{c}0.0710 * * * \\
(0.0138)\end{array}$ & $\begin{array}{c}0.0714 * * * \\
(0.0138)\end{array}$ & $\begin{array}{c}0.0294 * * * \\
(0.00440)\end{array}$ & $\begin{array}{c}0.0290 * * * \\
(0.00438)\end{array}$ & $\begin{array}{c}0.0290 * * * \\
(0.00438)\end{array}$ \\
\hline Size & $\begin{array}{l}-0.0151 \\
(0.0182)\end{array}$ & $\begin{array}{l}-0.0156 \\
(0.0183)\end{array}$ & $\begin{array}{l}-0.0154 \\
(0.0183)\end{array}$ & $\begin{array}{c}-0.0294 * * * \\
(0.0103)\end{array}$ & $\begin{array}{c}-0.0297 * * * \\
(0.0103)\end{array}$ & $\begin{array}{c}-0.0297 * * * \\
(0.0104)\end{array}$ \\
\hline Lag_Lev & $\begin{array}{l}0.0762 \\
(0.123)\end{array}$ & $\begin{array}{l}0.0775 \\
(0.124)\end{array}$ & $\begin{array}{l}0.0776 \\
(0.123)\end{array}$ & $\begin{array}{c}0.0258 \\
(0.0536)\end{array}$ & $\begin{array}{c}0.0266 \\
(0.0535)\end{array}$ & $\begin{array}{c}0.0265 \\
(0.0535)\end{array}$ \\
\hline ROA & $\begin{array}{l}1.205^{* *} \\
(0.577)\end{array}$ & $\begin{array}{l}1.063 * \\
(0.598)\end{array}$ & $\begin{array}{l}1.069 * \\
(0.599)\end{array}$ & $\begin{array}{l}-0.448 * \\
(0.241)\end{array}$ & $\begin{array}{c}-0.537 * * \\
(0.254)\end{array}$ & $\begin{array}{c}-0.538 * * \\
(0.254)\end{array}$ \\
\hline PPE & $\begin{array}{c}-0.114 \\
(0.0847)\end{array}$ & $\begin{array}{l}-0.0970 \\
(0.0829)\end{array}$ & $\begin{array}{l}-0.0977 \\
(0.0831)\end{array}$ & $\begin{array}{c}0.00217 \\
(0.0276)\end{array}$ & $\begin{array}{c}0.0127 \\
(0.0281)\end{array}$ & $\begin{array}{c}0.0129 \\
(0.0280)\end{array}$ \\
\hline SalesGrowth & $\begin{array}{c}0.246 \\
(0.282)\end{array}$ & $\begin{array}{c}0.227 \\
(0.281)\end{array}$ & $\begin{array}{c}0.236 \\
(0.279)\end{array}$ & $\begin{array}{l}0.00612 \\
(0.0614)\end{array}$ & $\begin{array}{r}-0.00561 \\
(0.0608)\end{array}$ & $\begin{array}{c}-0.00783 \\
(0.0606)\end{array}$ \\
\hline Constant & $\begin{array}{l}0.373 * \\
(0.209)\end{array}$ & $\begin{array}{c}0.257 \\
(0.209)\end{array}$ & $\begin{array}{c}0.320 \\
(0.212)\end{array}$ & $\begin{array}{c}1.106 * * * \\
(0.177)\end{array}$ & $\begin{array}{c}1.034 * * * \\
(0.167)\end{array}$ & $\begin{array}{c}1.019 * * * \\
(0.159)\end{array}$ \\
\hline Observations & 3,885 & 3,885 & 3,885 & 3,885 & 3,885 & 3,885 \\
\hline R-squared & $9.9 \%$ & $10.1 \%$ & $10.3 \%$ & $22.9 \%$ & $23.3 \%$ & $23.3 \%$ \\
\hline Firm Fixed Effects & No & No & No & No & No & No \\
\hline Year Fixed Effects & No & No & No & No & No & No \\
\hline Clustered SE by Firm & Yes & Yes & Yes & Yes & Yes & Yes \\
\hline
\end{tabular}

Note:

$* * *, * *, *$ denote significance at the $1 \%, 5 \%$, and $10 \%$ level, respectively, using two-tailed clustered standard errors at the firm level.

This table replicates our model from Table 3, Panels A-B, but without firm or year fixed-effects, to compare our estimates of TCJAtriggered contributions to GLV's lower bound estimates. In column (1) - (3), the dependent variable Voluntary Contributions is voluntary contributions aggregated at firm-level and scaled by lagged assets. In column (4) - (6), the dependent variable Mandatory Contributions is mandatory contributions made after the carryover and prefunding balance elected for use to offset funding requirements (aggregated at firm level) and scaled by lagged assets.

$T C J A$ is an indicator variable equal to 1 in fiscal years ending on March $31^{\text {st }}, 2017$ to November $30^{\text {th }}, 2018$, and equal to 0 in fiscal years ending before March 31 ${ }^{\text {st }}$, 2017. Taxpayer is an indicator variable equal to 1 (0) when federal tax expense plus total contributions reported on Form 5500 multiplied by the highest statutory tax rate (35\%) is greater (equal to or lesser) than zero. The variable of interest, Taxpayer*TCJA, is an interactive term. All other variables are defined in Appendix B. 
TABLE OA2

Estimates of TCJA-Triggered Contributions for comparison with GLV

\begin{tabular}{|c|c|c|c|}
\hline & & $\begin{array}{l}\text { No Fixed Effects } \\
\text { (Table OA1, col } 1 \\
\text { estimates) }\end{array}$ & $\begin{array}{c}\text { Firm Fixed Effects, } \\
\text { NO Year Fixed } \\
\text { Effects } \\
\text { (Table 3, col } 1 \\
\text { estimates) } \\
\end{array}$ \\
\hline \multicolumn{2}{|c|}{ Coefficient on TCJA } & 0.153 percent & 0.175 percent \\
\hline \multicolumn{2}{|c|}{$\begin{array}{l}\text { Our Estimates of Average TCJA-Triggered } \\
\text { Contributions }=[\text { Coefficient on TCJA } * \text { Pre-TCJA } \\
\left.\text { mean of total assets }{ }^{1}\right]\end{array}$} & $\begin{array}{r}0.153 \text { percent } * \\
\$ 22,206 \text { million }= \\
\$ 33.97 \text { million }\end{array}$ & $\begin{array}{r}0.175 \text { percent } * \\
\$ 22,206 \text { million }= \\
\$ 38.86 \text { million }\end{array}$ \\
\hline $\begin{array}{l}\text { For our } \\
\text { approxima } \\
\text { tion of } \\
\text { GLV's } \\
\text { sample }\end{array}$ & $\begin{array}{l}\text { Total TCJA-Triggered Contributions } \\
\text { from } 391 \text { observations in the TCJA } \\
\text { period }\end{array}$ & $\begin{array}{r}\$ 33.97 \text { million*391 } \\
=\mathbf{\$ 1 3 . 2 8} \text { billion }\end{array}$ & $\begin{array}{r}\$ 38.86 \text { million*391 } \\
=\$ \mathbf{\$ 1 5 . 1 9} \text { billion }\end{array}$ \\
\hline
\end{tabular}

This table provides the calculations for estimating TCJA-triggered contributions using our approximation of GLV's sample and our full sample for comparison. GLV's estimates of total TCJA-triggered contributions are based on models with no fixed effects and with firm (but no year) fixed effects. We apply GLV's sample selection criteria to all observations in Compustat Pension database. This yields a total of 1465 observations across 391 firms, with 391 observations in the TCJA period. The original GLV sample has 1469 observations across 389 firms, with 389 observations in the TCJA period.

${ }^{1}$ The mean of total assets in the pre-TCJA period is $\$ 22,206$ million as reported in Table 2, Panel A. 


\section{TABLE OA3}

\section{Univariate Difference-in-Differences Tests on PRT Transactions - Three Groups}

Difference in Means by Subgroup

\begin{tabular}{|c|c|c|c|c|c|c|c|c|c|c|}
\hline \multirow[b]{2}{*}{ Variable } & \multicolumn{3}{|c|}{ Before TCJA was Signed [A] } & \multicolumn{3}{|c|}{ After TCJA was Signed [B] } & \multicolumn{4}{|c|}{ Difference in Means } \\
\hline & $\mathbf{N}$ & Mean & SD & $\mathbf{N}$ & Mean & SD & {$[\mathrm{B}]-[\mathrm{A}]$} & SE & $\mathbf{t}$ & \\
\hline \multicolumn{11}{|c|}{ Sponsors that are least responsive to the TCJA (1) } \\
\hline Number of PRT completed & 1323 & 0.018 & 0.159 & 483 & 0.023 & 0.175 & 0.005 & 0.009 & 0.533 & \\
\hline Assets Transferred (unscaled) \$'m & 1318 & 6.083 & 92.495 & 482 & 14.639 & 274.062 & 8.556 & 8.642 & 0.990 & \\
\hline $\begin{array}{l}\text { Assets Transferred scaled by PBO } \\
\text { Assets Transferred (unscaled) for }\end{array}$ & 1309 & 0.002 & 0.023 & 482 & 0.003 & 0.025 & 0.001 & 0.001 & 0.817 & \\
\hline $\begin{array}{l}\text { observations involved in PRT } \\
\text { Assets Transferred (scaled by PBO) }\end{array}$ & 14 & 572.641 & 719.260 & 8 & 882 & 2070.469 & 309.359 & 600.644 & 0.515 & \\
\hline observations involved in PRT & 14 & 0.161 & 0.160 & 8 & 0.165 & 0.111 & 0.004 & 0.064 & 0.070 & \\
\hline \multicolumn{11}{|c|}{ Sponsors that are moderately responsive to the TCJA (2) } \\
\hline Number of PRT completed & 1344 & 0.022 & 0.153 & 480 & 0.048 & 0.266 & 0.026 & 0.010 & 2.544 & $* *$ \\
\hline Assets Transferred (unscaled) \$’m & 1329 & 6.971 & 127.772 & 480 & 21.533 & 220.656 & 14.562 & 8.404 & 1.733 & $*$ \\
\hline Assets Transferred scaled by PBO & 1329 & 0.001 & 0.017 & 480 & 0.007 & 0.059 & 0.006 & 0.002 & 3.340 & $* * *$ \\
\hline $\begin{array}{l}\text { Assets Transferred (unscaled) for } \\
\text { observations involved in PRT } \\
\text { Assets Transferred (scaled by PBO) }\end{array}$ & 14 & 661.750 & 1095.950 & 18 & 574.217 & 1017.769 & -87.533 & 375.007 & -0.233 & \\
\hline observations involved in PRT & 14 & 0.115 & 0.124 & 18 & 0.192 & 0.244 & 0.076 & 0.072 & 1.063 & \\
\hline \multicolumn{11}{|c|}{ Sponsors that are most responsive to the TCJA (3) } \\
\hline Number of PRT completed & 1337 & 0.025 & 0.173 & 492 & 0.051 & 0.277 & 0.026 & 0.011 & 2.400 & $* *$ \\
\hline Assets Transferred (unscaled) \$’m & 1331 & 43.255 & 938.585 & 489 & 33.861 & 273.867 & -9.394 & 43.110 & -0.218 & \\
\hline $\begin{array}{l}\text { Assets Transferred scaled by PBO } \\
\text { Assets Transferred (unscaled) for }\end{array}$ & 1328 & 0.002 & 0.021 & 489 & 0.010 & 0.076 & 0.008 & 0.002 & 3.410 & $* * *$ \\
\hline observations involved in PRT & 23 & 2503.155 & 6842.481 & 16 & 1034.887 & 1155.459 & -1468.27 & 1734.258 & -0.847 & \\
\hline
\end{tabular}


Assets Transferred (scaled by PBO)

observations involved in PRT

$23 \quad 0.129$

0.102

16

0.307

0.300

0.179

0.067

$2.654 * *$

\section{Difference-in-Differences}

\begin{tabular}{|c|c|c|c|c|c|c|c|}
\hline \multirow[b]{2}{*}{ Variable } & \multicolumn{3}{|c|}{ (3) vs. (1) } & & \multicolumn{3}{|c|}{ (3) vs. (2) } \\
\hline & DiD & SE & $\mathbf{t}$ & & DiD & SE & $\mathbf{t}$ \\
\hline Number of PRT completed & 0.028 & 0.015 & 1.885 & $*$ & 0.003 & 0.017 & 0.166 \\
\hline Assets Transferred (unscaled) \$'m & 19.222 & 17.584 & 1.093 & & 12.328 & 15.995 & 0.771 \\
\hline Assets Transferred scaled by PBO & 0.007 & 0.004 & 2.009 & $* *$ & 0.003 & 0.004 & 0.656 \\
\hline $\begin{array}{l}\text { Assets Transferred (unscaled) for } \\
\text { observations involved in PRT } \\
\text { Assets Transferred (scaled by PBO) }\end{array}$ & 152.888 & 653.014 & 0.234 & & 460.671 & 372.622 & 1.236 \\
\hline observations involved in PRT & 0.142 & 0.111 & 1.282 & & 0.116 & 0.093 & 1.237 \\
\hline
\end{tabular}

Note:

$* * *, * *, *$ denote significance at the $1 \%, 5 \%$, and $10 \%$ level, respectively (two-tailed tests).

The TCJA was signed on December $22^{\text {nd }}, 2017$. We partition the sample by responsiveness of sponsors to the TCJA. Responsiveness of sponsors to the TCJA is captured by the change in funding ratio between post-TCJA and pre-TCJA period ( $\triangle$ FundRatio_GAAP). Sponsors that are least responsive to the TCJA are those ranking in the lowest tercile of $\triangle$ FundRatio_GAAP while sponsors that are moderately responsive are those ranking in the middle tercile, and sponsors that are most responsive to the TCJA are those ranking in the highest tercile of $\triangle$ FundRatio_GAAP. "Number of PRT completed" describes an indicator variable set to one if a PRT transaction was completed, and to zero if not. "Assets transferred (unscaled) \$'m" describes the value of pension assets transferred in the PRT transaction, with the value set to zero for firm-years with no PRT. "Assets transferred scaled by PBO" describes the value of pension assets transferred in the PRT transaction / beginning-of-year PBO, with the value set to zero for firm-years with no PRT. 